\title{
Selective copper recovery from ammoniacal waste streams using a systematic
}

\section{biosorption process}

Nina Ricci Nicomel ${ }^{\mathrm{a},{ }^{,}}$, Lila Otero-Gonzalez ${ }^{\mathrm{a}, \mathrm{I}}$, Adam Williamson ${ }^{\mathrm{b}}$, Yong Sik $\mathrm{Ok}^{\mathrm{c}}$, Pascal Van

Der Voort $^{\mathrm{d}}$, Tom Hennebel ${ }^{\mathrm{b}}$, Gijs Du Laing ${ }^{\mathrm{a}}$

${ }^{a}$ Laboratory of Analytical Chemistry and Applied Ecochemistry, Department of Green Chemistry and Technology, Ghent University, Coupure Links 653, 9000 Ghent, Belgium

${ }^{\mathrm{b}}$ Center for Microbial Ecology and Technology, Department of Biochemical and Microbial Technology, Ghent University, Coupure Links 653, 9000 Ghent, Belgium

${ }^{\mathrm{c}}$ Korea Biochar Research Center, APRU Sustainable Waste Management Program and Division of Environmental Science and Ecological Engineering, Korea University, Seoul, Republic of Korea

${ }^{\mathrm{d}}$ Center for Ordered Materials, Organometallics and Catalysis, Department of Chemistry, Ghent University, Krijgslaan 281 (S3), 9000 Ghent, Belgium

* Corresponding author:

E-mail: NinaRicci.Nicomel@UGent.be

Tel.: +3292646131

Fax: +3292646232

Present address:

I IDENER, Earle Ovington 24, 8-9, 41300 La Rinconada, Seville, Spain

(C) 2021. This manuscript version is made available under the CC-BY-NC-ND 4.0 license http://creativecommons.org/licenses/by-nc-nd/4.0/

Link to the formal publication: $\underline{\text { https://doi.org/10.1016/j.chemosphere.2021.131935 }}$ 


\section{Highlights}

- A top-down approach optimized $\mathrm{Cu}$ biosorption from a real $\mathrm{Cu}-\mathrm{NH}_{3}$ leachate

- Pinecone (PC) has a high $\mathrm{Cu} q_{\max }$ of $1.1 \mathrm{mmol} \mathrm{g}^{-1}$ despite $2 \mathrm{M} \mathrm{NH}_{3}$ and $5 \mathrm{mM} \mathrm{Zn}$ present

- $\mathrm{PC}$ works over wide $\mathrm{pH}$ range (5-12) relevant for treating $\left(\mathrm{NH}_{4}\right)_{2} \mathrm{CO}_{3}$ rich effluents

- $\quad \mathrm{PC}$ has a selectivity quotient $\left(K_{C u / Z n}\right)$ of 3.97 making it selective for $\mathrm{Cu}$ over $\mathrm{Zn}$

- The presence of $\mathrm{Zn}$ can improve the $q_{\max }$ of $\mathrm{PC}$ for $\mathrm{Cu}$ from $\mathrm{NH}_{3}$-rich streams 


\section{ABSTRACT}

$\mathrm{Cu}-\mathrm{NH}_{3}$ bearing effluents arise from electroplating and metal extraction industries, requiring innovative and sustainable $\mathrm{Cu}$ recovery technologies to reduce their adverse environmental impact. $\mathrm{CO}_{3}{ }^{2-}$ and $\mathrm{Zn}$ are often co-occurring, and thus, selective $\mathrm{Cu}$ recovery from these complex liquid streams is required for economic viability. This study assessed 23 sustainable biosorbents classified as tannin-rich, lignin-rich, chitosan/chitin, dead biomass, macroalgae or biochar for their $\mathrm{Cu}$ adsorption capacity and selectivity in a complex $\mathrm{NH}_{3}$-bearing bioleachate. Under a preliminary screen with $12 \mathrm{mM} \mathrm{Cu}$ in $1 \mathrm{M}$ ammoniacal solution, most biosorbents showed optimal $\mathrm{Cu}$ adsorption at $\mathrm{pH} 11$, with pinecone remarkably showing high removal efficiencies (up to 68\%) at all tested pH values. Further refinements on select biosorbents with $\mathrm{pH}$, contact time, and presence of $\mathrm{NH}_{3}, \mathrm{Zn}$ and $\mathrm{CO}_{3}{ }^{2-}$ showed again that pinecone has a high maximum adsorption capacity $\left(1.07 \mathrm{mmol} \mathrm{g}^{-1}\right)$, worked over $\mathrm{pH}$ 5-12 and was $\mathrm{Cu}$-selective with 3.97 selectivity quotient $\left(K_{C u / Z n}\right)$. Importantly, pinecone performance was maintained in a real $\mathrm{Cu} / \mathrm{NH}_{3} / \mathrm{Zn} / \mathrm{CO}_{3}{ }^{2-}$ bioleachate, with $69.4 \% \mathrm{Cu}$ removal efficiency. Unlike synthetic adsorbents, pinecones require no pre-treatment, which together with its abundance, selectivity, and efficiency without the need for prior $\mathrm{NH}_{3}$ removal, makes it a competitive and sustainable $\mathrm{Cu}$ biosorbent for complex $\mathrm{Cu}-\mathrm{NH}_{3}$ bearing streams. Overall, this study demonstrated the potential of integrating bioleaching and biosorption as a clean $\mathrm{Cu}$ recovery technology utilizing only sustainable resources (i.e., bio-lixiviant and biosorbents). This presents a closed-loop approach to $\mathrm{Cu}$ extraction and recovery from wastes, thus effectively addressing elemental sustainability.

Keywords: copper, ammonia, adsorption, waste processing, selectivity 


\section{Introduction}

Copper $(\mathrm{Cu})$ and ammonia $\left(\mathrm{NH}_{3}\right)$ are two of the most used raw materials in many industrial processes, including printed circuit board (PCB) manufacturing and electroplating (Egenhofer et al., 2014; Al-Saydeh et al., 2017). Due to their extensive use, $\mathrm{Cu}$ and $\mathrm{NH}_{3}$ are frequently found in the effluents of these processes at elevated levels. In PCB manufacturing, spent etching solutions can have $\mathrm{Cu}$ and $\mathrm{NH}_{3}$ contents reaching up to 0.82 and $3.5 \mathrm{M}$, respectively, which present significant quantities of recoverable resources considering that the global PCB industry generates about $10^{12} \mathrm{~L}$ of waste etchant annually (Shah et al., 2018). Alternately, $\mathrm{NH}_{3}$ has been recognized as an effective lixiviant in (bio)hydrometallurgical $\mathrm{Cu}$ extraction, resulting in $\mathrm{Cu}$ and $\mathrm{NH}_{3}$ bearing liquid streams (i.e., leachates) with $\mathrm{Cu}$ concentrations exceeding 1.1 M (Xiao et al., 2013; Williamson et al., 2020). Considering the continuously growing global $\mathrm{Cu}$ demand (23.23 Mt in 2019) and the reduction in number of easily accessible primary $\mathrm{Cu}$ ores, $\mathrm{Cu}$ and $\mathrm{NH}_{3}$-rich streams offer secondary resources to ensure sustainable $\mathrm{Cu}$ supply in the long run (Garside, 2020). However, these streams can be complex due to the co-occurrence of other components (e.g., $\mathrm{Zn}, \mathrm{CO}_{3}{ }^{2-}$ ) and can have variable $\mathrm{pH}$ values mostly between $\mathrm{pH} 9$ and 12 , which can impact the $\mathrm{Cu}$ recovery process (Xiao et al., 2013; Chai et al., 2017; Williamson et al., 2020).

$\mathrm{Cu}$ recycling from aqueous secondary resources has been widely studied in the past to address resource availability concerns and to reduce the environmental burdens associated with primary $\mathrm{Cu}$ processing (Al-Saydeh et al., 2017; Ciacci et al., 2020). However, many $\mathrm{Cu}$ recycling studies have dealt with single metal solutions despite the multicomponent nature of real industrial effluents, which can potentially modify the type of interactions among the components and consequently affect the efficiency of the employed $\mathrm{Cu}$ recovery technology (Peng et al., 2011; Hu et al., 2017). The conventional $\mathrm{Cu}$ recovery technologies (i.e., hydroxide precipitation, ion exchange, membrane filtration, and electrochemical methods) are mostly 
inefficient in multicomponent solutions such as ammoniacal streams due to the formation of stable $\mathrm{Cu}-\mathrm{NH}_{3}$ complexes that are hard to break (Fu and Wang, 2011; Chai et al., 2017). Furthermore, their applications are usually hindered by high energy and chemical requirements, high capital costs, and the generation of voluminous by-products (Fu and Wang, 2011). Thus, alternative technologies are gaining attention for the sustainable and effective extraction, recovery and reuse of this economically important metal from secondary resources.

Adsorption has been considered as an alternative $\mathrm{Cu}$ recovery technology owing to its easy and low-cost operation, sustainability, and effectiveness even in complex solutions (Al-Saydeh et al., 2017). The systematic selection of adsorbent with high adsorption capacity and selectivity is essential to any adsorption process. Some adsorbents, including commercial silica gel, magnetic ferrite nanoparticles, and metal oxides (e.g., $\mathrm{TiO}_{2}$ and $\mathrm{SnO}_{2}$ ), have been investigated for $\mathrm{Cu}$ removal from ammoniacal solutions (Kar et al., 1975; Kar et al., 1976; Baba et al., 1984; Fuerstenau and Osseo-Asare, 1987). However, the unsustainable and costly materials used to synthesize these adsorbents are unjustified in environmental applications. Furthermore, most studies have used low $\mathrm{NH}_{3}$ concentrations and solution $\mathrm{pH}$ ranges that are not representative of real $\mathrm{Cu}-\mathrm{NH}_{3}$ streams. The selection of these experimental conditions highlights the repetitive and limiting system employed in most adsorption studies, wherein a particular adsorbent is selected without an order and subsequently tested for different conditions with no target applications.

Alternatively, adsorbents from natural sources (i.e., biosorbents) can offer a sustainable and practical substitute for the synthetic adsorbents. To date, biosorbents have not been investigated for their capacity to remove $\mathrm{Cu}$ from ammoniacal streams, although they naturally possess surface functional groups, including carboxylic, amino, and phenolic-type surface groups, which have been reported to influence $\mathrm{Cu}$ adsorption (Gerente et al., 2007; He and Chen, 2014; Inyang et al., 2016). In some cases where ligands are present in the solution, the 
biosorbent efficiency and selectivity can even be enhanced if the ligand functional groups responsible for metal complexation are not involved in binding the ligand to the biosorbent surface (Elliott and Huang, 1979). Metal-biosorbent surface interaction is a complex and unpredictable process that is highly dependent on the environmental conditions. Thus, although many biosorbents have been previously studied for $\mathrm{Cu}$ adsorption, their efficiency and suitability for a particular stream cannot be directly compared given the differences in the experimental conditions used. A more holistic approach, such as a biosorption screening framework, reflecting the same range of conditions for all biosorbents would be more useful in generating information on adsorption capacity and selectivity.

While there has been an increasing number of biosorption-based $\mathrm{Cu}$ recovery studies using single-metal solutions, $\mathrm{Cu}$ recovery from complex solutions containing $\mathrm{NH}_{3}$ and other ions is lacking. It is established that metal speciation changes in the presence of other ions and this largely influences metal adsorption. Recently, Williamson et al. (2020) has demonstrated that biogenic $\mathrm{NH}_{3}$ can be a potent lixiviant for $\mathrm{Cu}$ and $\mathrm{Zn}$ extraction from heterogeneous automotive shredder residues (ASR), offering a greener lixiviant production route and $\mathrm{Cu}$ secondary resource. In order to close the loop and make such technology more feasible, the bioleaching process should be coupled with a technology that could efficiently and selectively recover $\mathrm{Cu}$ from the leachate despite the presence of $\mathrm{NH}_{3}$ and other ions. In the present work, a set of 23 biosorbents was screened for the adsorption of $\mathrm{Cu}$ from a synthetic $\mathrm{Cu}-\mathrm{NH}_{3}$ leachate. $\mathrm{An}$ in-depth investigation of the adsorption of $\mathrm{Cu}-\mathrm{NH}_{3}$ complexes using five biosorbents (i.e., pinecone, Fucus spiralis, chitosan, sewage sludge biochar, and lignin-rich digested stillage) was subsequently performed by studying the influence of kinetics, solution $\mathrm{pH}$, and presence of other ions (i.e., $\mathrm{Zn}, \mathrm{CO}_{3}{ }^{2-}$ ) in the solution. Finally, a combination of optimal parameters and biosorbent was applied to the real $\mathrm{Cu}-\mathrm{NH}_{3}$ bearing leachate 
containing $\mathrm{Cu}, \mathrm{NH}_{3}, \mathrm{CO}_{3}{ }^{2-}$, and $\mathrm{Zn}$ (Williamson et al., 2020) to test our selection method and validate our findings.

\section{Materials and Methods}

\subsection{Biosorbents}

The biosorbents used in this study (Table 1) were selected based on positive reports in the literature identifying some of the most efficient $\mathrm{Cu}(\mathrm{II})$ biosorbents. These materials were classified according to the following biosorbent categories: bark/tannin-rich materials, ligninrich materials, chitin/chitosan, dead biomass, macroalgae, and biochars (Bailey et al., 1999). The tannin-rich materials were obtained from natural sources including residues from woodworks, cacao production, and tea consumption. The lignin-rich agricultural bio-wastes wheat straw and hay were obtained commercially. The lignin-rich digested stillage was obtained from lignocellulosic ethanol production and subsequent anaerobic digestion (Ghysels et al., 2019). Chitosan with medium molecular weight was purchased from Sigma-Aldrich (St. Louis, MO, USA). Microalgal biomass was provided by GEMMA at Universitat Politècnica de Catalunya (Barcelona, Spain). The waste yeast was obtained from a local Belgian brewery. Macroalgal species were collected in Goes, The Netherlands with the help of the Phycology Research Group at Ghent University. Biochars were provided by the Korea Biochar Research Center. The biosorbents, except chitosan, were washed with deionized water several times and then dried in an oven at $60{ }^{\circ} \mathrm{C}$ for at least $48 \mathrm{~h}$. The dried biosorbents were crushed and sieved to a particle size of $<1 \mathrm{~mm}$.

Table 1. List of the biosorbents used for the removal of $\mathrm{Cu}$ (II) from ammoniacal solution in the preliminary screening experiment.

\begin{tabular}{llll}
\hline Biosorbent & Code & Description & Reference \\
\hline Bark/tannin- & PC & Pinecone & Ofomaja et al. (2009) \\
rich materials & RCS & Roasted cacao shells & Meunier et al. (2003) \\
& SD & Sawdust & Rahman and Islam (2009) \\
& BTW & Black tea waste & Weng et al. (2014) \\
\hline
\end{tabular}




\begin{tabular}{|c|c|c|c|}
\hline Lignin-rich & WS & Wheat straw & Han et al. (2010) \\
\hline \multirow{2}{*}{ materials } & HY & $\mathrm{Hay}^{\dagger}$ & Bailey et al. (1999) \\
\hline & LRD & Lignin-rich digested stillage $^{\dagger}$ & Bailey et al. (1999) \\
\hline \multirow[t]{2}{*}{ Chitin/chitosan } & $\mathrm{CT}$ & Chitosan & Gerente et al. (2007) \\
\hline & CS & Crab shells & Vijayaraghavan et al. (2006) \\
\hline \multirow[t]{2}{*}{ Dead biomass } & WY & Waste yeast & Cojocaru et al. (2009) \\
\hline & $\mathrm{HC}$ & Microalgae $^{\dagger}$ & Bailey et al. (1999) \\
\hline \multirow[t]{8}{*}{ Macroalgae } & SM & Sargassum muticum $^{\dagger}$ & He and Chen (2014) \\
\hline & FS & Fucus spiralis & Murphy et al. (2007) \\
\hline & GG & Gracilaria gracilis $^{\dagger}$ & He and Chen (2014) \\
\hline & GT & Grateloupia turuturu $^{\dagger}$ & He and Chen (2014) \\
\hline & AS & Agardhiella subulata ${ }^{\dagger}$ & He and Chen (2014) \\
\hline & UR & Ulva rigida & He and Chen (2014) \\
\hline & UC & Ulva compressa & Murphy et al. (2007) \\
\hline & $\mathrm{CF}$ & Codium fragile ${ }^{\dagger}$ & He and Chen (2014) \\
\hline \multirow[t]{4}{*}{ Biochar } & SSBC500 & Sewage sludge biochar & Otero et al. (2009) \\
\hline & RHBC500 & Rice husk biochar ${ }^{\ddagger}$ & Pellera et al. (2012) \\
\hline & PCBC200 & Pinecone biochar ${ }^{\dagger}, *$ & Inyang et al. (2016) \\
\hline & PCBC500 & Pinecone biochar ${ }^{\dagger, \ddagger}$ & Inyang et al. (2016) \\
\hline
\end{tabular}

${ }^{\dagger}$ References represent the closest literature match to the enlisted biosorbents; ${ }^{\star}$ Pyrolyzed at 500 ${ }^{\circ} \mathrm{C}$; *Pyrolyzed at $200{ }^{\circ} \mathrm{C}$

\subsection{Screening of the biosorbents}

The biosorbents listed in Table 1 were screened for their $\mathrm{Cu}(\mathrm{II})$ removal efficiencies in the presence of $\mathrm{NH}_{3}$ at different $\mathrm{pH}$ values $(9,10,11$ and 12). Four working solutions containing $12 \mathrm{mM} \mathrm{Cu}(\mathrm{II})$ as $\mathrm{Cu}\left(\mathrm{NO}_{3}\right)_{2} \cdot 2.5 \mathrm{H}_{2} \mathrm{O}$ (Chem-Lab NV, Belgium) and $1 \mathrm{M} \mathrm{NH}_{3}(25 \mathrm{wt} \%$, ChemLab NV, Belgium) were prepared by mixing known volumes of $200 \mathrm{mM} \mathrm{Cu(II)} \mathrm{stock} \mathrm{solution}$ and $\mathrm{NH}_{3}$ solution, then diluted with deionized water to the correct volume. The $\mathrm{pH}$ of each solution was adjusted to a value from 9-12 with one $\mathrm{pH}$ unit increment using either concentrated $\mathrm{HNO}_{3}$ or $10 \mathrm{M} \mathrm{NaOH}$. Batch experiments were performed by adding $10 \mathrm{~mL}$ of the working solution to $100 \mathrm{mg}$ of the biosorbent weighed in a 12 -mL polypropylene tube $\left(100 \mathrm{~mL} \mathrm{~g}^{-1}\right.$ liquidto-solid (L/S) ratio). The samples were shaken using an orbital shaker at $115 \mathrm{rpm}$ for 24 hours. After measuring the final $\mathrm{pH}$ using a Thermo Scientific Orion Star A211 pH meter, the suspensions were filtered using Whatman cellulose filter papers $(11-\mu \mathrm{m}$ pore size). The $\mathrm{Cu}$ concentration in the filtrates was determined by inductively coupled plasma optical emission 
spectroscopy (Varian Vista-MPX CCD Simultaneous ICP-OES). All experiments were conducted in duplicate and the data presented are mean values with standard deviation. Control samples were prepared without biosorbent to estimate the $\mathrm{Cu}(\mathrm{II})$ precipitation at different $\mathrm{pH}$ values. The $\mathrm{Cu}(\mathrm{II})$ removal efficiency and adsorption capacity of the biosorbents were calculated using Eq. A.1 and A.2 (Appendix A: Supplementary Data), respectively.

Based on the results of the screening, five biosorbents from different categories were selected for the succeeding experiments: pinecone (PC), Fucus spiralis (FS), chitosan (CT), sewage sludge biochar (SSBC500), and lignin-rich digested stillage (LRD). The effects of $\mathrm{pH}$, contact time, $\mathrm{NH}_{3}$ concentration, and presence of $\mathrm{Zn}(\mathrm{II})$ and $\mathrm{CO}_{3}{ }^{2-}$ on $\mathrm{Cu}$ (II) adsorption onto each of these biosorbents were investigated.

\subsection{Effect of $\mathrm{pH}$ on $\mathrm{Cu}(\mathrm{II})$ biosorption in the presence of $\mathrm{NH}_{3}$}

Using PC, FS, CT, SSBC500, and LRD, the dependence of $\mathrm{Cu}(\mathrm{II})$ adsorption on the solution $\mathrm{pH}$ was investigated in batch experiments at two different $\mathrm{NH}_{3}$ concentrations. Six solutions with $\mathrm{pH}$ of $3,6,7.5,9,11$, and 12 were prepared containing $5 \mathrm{mM} \mathrm{Cu}(\mathrm{II})$ and either 1 or $2 \mathrm{M}$ $\mathrm{NH}_{3}$. The samples were prepared by adding $10 \mathrm{~mL}$ of the $\mathrm{Cu}-\mathrm{NH}_{3}$ solutions to $100 \mathrm{mg}$ of biosorbent. After shaking the samples for 24 hours, all samples were filtered and analyzed for $\mathrm{Cu}$ concentration as described in Section 2.2.

\section{4. $\mathrm{Cu}(\mathrm{II})$ biosorption kinetics}

Kinetic studies were performed to investigate the adsorption of $\mathrm{Cu}(\mathrm{II})$ in the presence of $\mathrm{NH}_{3}$ as a function of time. The biosorbents were put in contact with $10 \mathrm{~mL}$ of a solution $(\mathrm{pH}$ 11) containing $5 \mathrm{mM} \mathrm{Cu}(\mathrm{II})$ and $2 \mathrm{M} \mathrm{NH}_{3}$ at an $\mathrm{L} / \mathrm{S}$ ratio of $100 \mathrm{~mL} \mathrm{~g}^{-1}$. The suspensions were shaken for different time intervals ranging from 15 minutes to 24 hours. After each time interval, the samples were filtered and analyzed for $\mathrm{Cu}$ concentration as described in Section 2.2. 


\subsection{Biosorption isotherms}

The adsorption of $\mathrm{Cu}(\mathrm{II})$ on the selected biosorbents was assessed at different initial $\mathrm{Cu}$ concentrations to determine the maximum adsorption capacities $\left(q_{\max }\right)$ of the biosorbents at $\mathrm{pH}$ 11. The samples were handled in the same way as described in Section 2.2, except that the initial $\mathrm{NH}_{3}$ concentration was $2 \mathrm{M}$, while the initial $\mathrm{Cu}$ (II) concentration varied from 5-100 mM. After filtering, the $\mathrm{Cu}$ concentrations of the filtrate were measured using ICP-OES. Langmuir (Eq. A.3) and Freundlich (Eq. A.4) isotherm models were used to fit the experimental data to estimate the maximum adsorption capacities of the biosorbents. The adsorption isotherms and the corresponding parameters were determined using SigmaPlot v13.0.

\subsection{Selectivity between $\mathrm{Cu}(I I)$ and $\mathrm{Zn}(I I)$}

Batch experiments were conducted to investigate competition effects and selectivity between $\mathrm{Cu}(\mathrm{II})$ and $\mathrm{Zn}(\mathrm{II})$. A solution containing $50 \mathrm{mM} \mathrm{Cu}(\mathrm{II}), 50 \mathrm{mM} \mathrm{Zn}(\mathrm{II})$ as $\mathrm{Zn}\left(\mathrm{NO}_{3}\right.$ )$_{2} \cdot 6 \mathrm{H}_{2} \mathrm{O}$ (Merck, Germany), and $2 \mathrm{M} \mathrm{NH}_{3}$ was prepared at $\mathrm{pH} 11$. The initial $\mathrm{Cu}$ (II) concentration used was based on the concentration where the biosorbents exhibited saturation, while $\mathrm{Zn}$ (II) was set to have an equimolar concentration. When biosorbents are saturated, the competition for adsorption sites is maximized, leading to correct assessment of the selectivity between $\mathrm{Cu}(\mathrm{II})$ and $\mathrm{Zn}(\mathrm{II})$. The samples were prepared and analyzed for $\mathrm{Cu}$ and $\mathrm{Zn}$ concentration by ICP-OES as described in Section 2.2. Selectivity quotients $\left(K_{C u / Z n}\right)$, given by Eq. A.5 (Kar et al., 1976), were calculated to compare the ability of the biosorbents to selectively adsorb $\mathrm{Cu}(\mathrm{II})$ over $\mathrm{Zn}(\mathrm{II})$ from a system of $50 \mathrm{mM} \mathrm{Cu}(\mathrm{II}), 50 \mathrm{mM} \mathrm{Zn(II),} \mathrm{and} 2 \mathrm{M}$ $\mathrm{NH}_{3}$.

The $q_{\max }$ of the five biosorbents for $\mathrm{Cu}$ (II) were re-evaluated in the presence of $\mathrm{Zn}$ (II) to assess how $\mathrm{Zn}(\mathrm{II})$ will impact the $q_{\max }$ values obtained in a single-metal solution. This experiment was set up as described in Section 2.5, but using a multimetal solution containing 
both $\mathrm{Zn}(\mathrm{II})$ and $\mathrm{Cu}(\mathrm{II})$. The initial $\mathrm{pH}$ used was $\mathrm{pH} 11$ and the amount of $\mathrm{Zn}$ (II) added to the solution was $5 \mathrm{mM}$.

\subsection{Effect of carbonate on $\mathrm{Cu}(\mathrm{II})$ biosorption}

The effect of $\mathrm{CO}_{3}{ }^{2-}$ on the adsorption of $\mathrm{Cu}$ (II) was investigated in batch experiments. Two solutions with initial $\mathrm{pH}$ of 9 and 11 were prepared, each containing $5 \mathrm{mM} \mathrm{Cu(II),} 2 \mathrm{M} \mathrm{NH}_{3}$, and $1 \mathrm{M} \mathrm{CO}_{3}{ }^{2-}$ added as $\left(\mathrm{NH}_{4}\right)_{2} \mathrm{CO}_{3}\left(\geq 30 \% \mathrm{NH}_{3}\right.$ basis, Sigma-Aldrich, USA). The samples were handled and analyzed for $\mathrm{Cu}$ concentration as described in Section 2.2.

\section{8. $\mathrm{Cu}($ II) biosorption from real leachates}

PC, FS, CT, SSBC500, and LRD were tested for $\mathrm{Cu}(\mathrm{II})$ adsorption from a real leachate (pH 11.1) derived from the extraction of $\mathrm{ASR}$, which contained $6 \mathrm{mM} \mathrm{Cu}(\mathrm{II}), 1.1 \mathrm{mM} \mathrm{Zn}(\mathrm{II}), 1$ $\mathrm{M} \mathrm{NH}_{3}$, and $0.5 \mathrm{M} \mathrm{CO}_{3}{ }^{2-}$ (Williamson et al., 2020). A simplified synthetic leachate with approximately the same composition was prepared as a reference. The samples were prepared and analyzed as described in Section 2.2.

\section{Results and Discussion}

\subsection{Screening of the biosorbents}

An initial screen of 23 biosorbents was performed between $\mathrm{pH} 9-12$ to determine the optimal biosorbent and $\mathrm{pH}$ for the biosorption of $\mathrm{Cu}$ (II) from a solution of $12 \mathrm{mM} \mathrm{Cu}$ (II) and $1 \mathrm{M} \mathrm{NH}_{3}$ (Fig. 1). No systematic biosorption trend within the same category was observed. Most biosorbents showed poor $(<20 \%) \mathrm{Cu}(\mathrm{II})$ adsorption at $\mathrm{pH} 9$ and 10, with $\mathrm{Cu}$ speciation (Fig. A.1) modeled solely as $\mathrm{Cu}\left(\mathrm{NH}_{3}\right)_{4}{ }^{2+}$. In general, $\mathrm{Cu}(\mathrm{II})$ removal efficiencies were higher at $\mathrm{pH}$ 11 (increase $<15 \%$ ), where both $\mathrm{Cu}\left(\mathrm{NH}_{3}\right)_{4}{ }^{2+}$ and $\mathrm{Cu}\left(\mathrm{NH}_{3}\right)_{3} \mathrm{OH}^{+}$are present in equal fractions. Enhanced adsorption at $\mathrm{pH} 11$ could be attributed to the presence of the hydroxide ligand, which can increase the probability of adsorption through interfacial hydrogen bonding with the surface functional groups of the biosorbents (Fuerstenau and Osseo-Asare, 1987; Crawford et al., 1997). Furthermore, the enhanced adsorption at higher $\mathrm{pH}$ values can be attributed to increased 
coulombic interaction (Fuerstenau and Osseo-Asare, 1987), with negatively charged surfaces attracting $\mathrm{Cu}\left(\mathrm{NH}_{3}\right)_{4}{ }^{2+}$ and $\mathrm{Cu}\left(\mathrm{NH}_{3}\right)_{3} \mathrm{OH}^{+}$. At $\mathrm{pH} 12$, a removal of $25 \%$ was observed in the control, likely due to the formation of $\mathrm{Cu}(\mathrm{OH})_{2}$ precipitates. After correcting for this, the $\mathrm{Cu}(\mathrm{II})$ adsorption was generally less at $\mathrm{pH} 12$ than at $\mathrm{pH} 11$, with more than half of the biosorbents showing reduced removal efficiencies $(<25 \%)$.

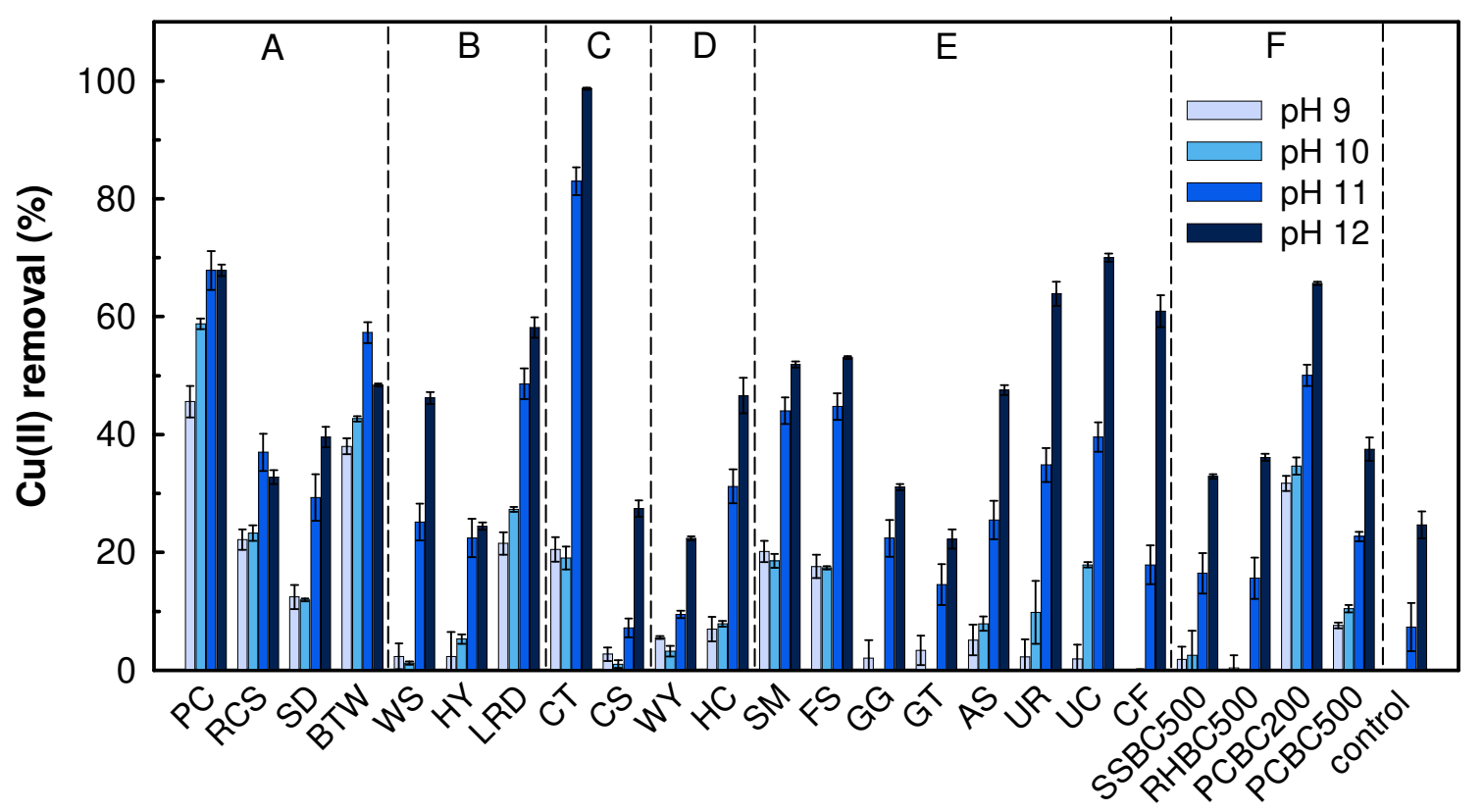

Fig. 1. $\mathrm{Cu}(\mathrm{II})$ removal efficiencies of different biosorbents in ammoniacal solutions with different $\mathrm{pH}$ values. Experimental conditions: $12 \mathrm{mM} \mathrm{Cu(II),} 1 \mathrm{M} \mathrm{NH}_{3}, 100 \mathrm{~mL} \mathrm{~g}^{-1} \mathrm{~L} / \mathrm{S}$ ratio, room temperature $\left(\mathrm{RT}, 20 \pm 2{ }^{\circ} \mathrm{C}\right), 24 \mathrm{~h}$ contact time. Note: The biosorbents were grouped according to the categories (A) tannin-rich materials, (B) lignin-rich materials, (C) chitin/chitosan, (D) dead biomass, (E) macroalgae, and (F) biochar.

This preliminary experiment provided a first approximation of the $\mathrm{Cu}(\mathrm{II})$ adsorption behavior of the biosorbents in the presence of $\mathrm{NH}_{3}$. Based on the results, five biosorbents were selected for further study, namely PC, FS, CT, SSBC500, and LRD. The tannin-rich PC showed relatively good removal efficiencies regardless of the $\mathrm{pH}$ and was the most efficient biosorbent at $\mathrm{pH} 9(46 \%)$ and $10(59 \%)$. CT had the highest $\mathrm{Cu}(\mathrm{II})$ removal at $\mathrm{pH} 11(83 \%)$, while the 
alginate-rich FS and lignin-rich LRD both have acceptable removal efficiencies at $\mathrm{pH} 11$. While exhibiting poor $\mathrm{Cu}$ affinities, SSBC500 was selected to identify which surface properties are unfavorable for $\mathrm{Cu}$ (II) adsorption. PC, FS, CT, SSBC500, and LRD were characterized by performing point of zero charge ( $\mathrm{pH}$ PZC $)$ determination, pore structure characterization, acidic and basic surface properties determination (Table A.1), and FTIR spectroscopy (Table A.2). These biosorbents and any similar ones have not been reported to remove $\mathrm{Cu}-\mathrm{NH}_{3}$ complexes before. Most studies concerning $\mathrm{Cu}(\mathrm{II})$ adsorption from ammoniacal solutions used commercial silica gel and synthetic or natural oxides (Kar et al., 1975; Kar et al., 1976; Baba et al., 1984; Fuerstenau and Osseo-Asare, 1987).

\subsection{Effect of $\mathrm{pH}$ and $\mathrm{NH}_{3}$ concentration on $\mathrm{Cu}(\mathrm{II})$ removal}

Metal speciation varies over a wide $\mathrm{pH}$ range and this has an important role in optimizing metal adsorption processes. Thus, $\mathrm{Cu}(\mathrm{II})$ adsorption $(5 \mathrm{mM})$ by PC, FS, CT, SSBC500, and LRD was assessed from $\mathrm{pH} 3$ to 12 in the presence of $1 \mathrm{M}$ or $2 \mathrm{M} \mathrm{NH}_{3}$ to determine the influence of $\mathrm{Cu}$ (II) speciation on the optimum $\mathrm{pH}$ for $\mathrm{Cu}$ (II) adsorption (Fig. 2). Except that of SSBC500, $\mathrm{Cu}$ (II) adsorption increased by $4-72 \%$ as the $\mathrm{pH}$ increased from 3 to 6 . A drop in $\mathrm{Cu}$ (II) adsorption of up to $95 \%$ was observed between $\mathrm{pH} 6$ and 9, followed by another increase from pH 9 to 12. Furthermore, as the $\mathrm{NH}_{3}$ concentration increased from 1 to $2 \mathrm{M}$, only a small decrease in the $\mathrm{Cu}(\mathrm{II})$ removal efficiencies was observed, except for $\mathrm{CT}$ which showed a decrease of $55 \%$ at $\mathrm{pH} 11$. Metal adsorption capacities decrease in the presence of excess $\mathrm{NH}_{3}$, which compete with metal ions for the biosorbent surface sites (Kar et al., 1976). 


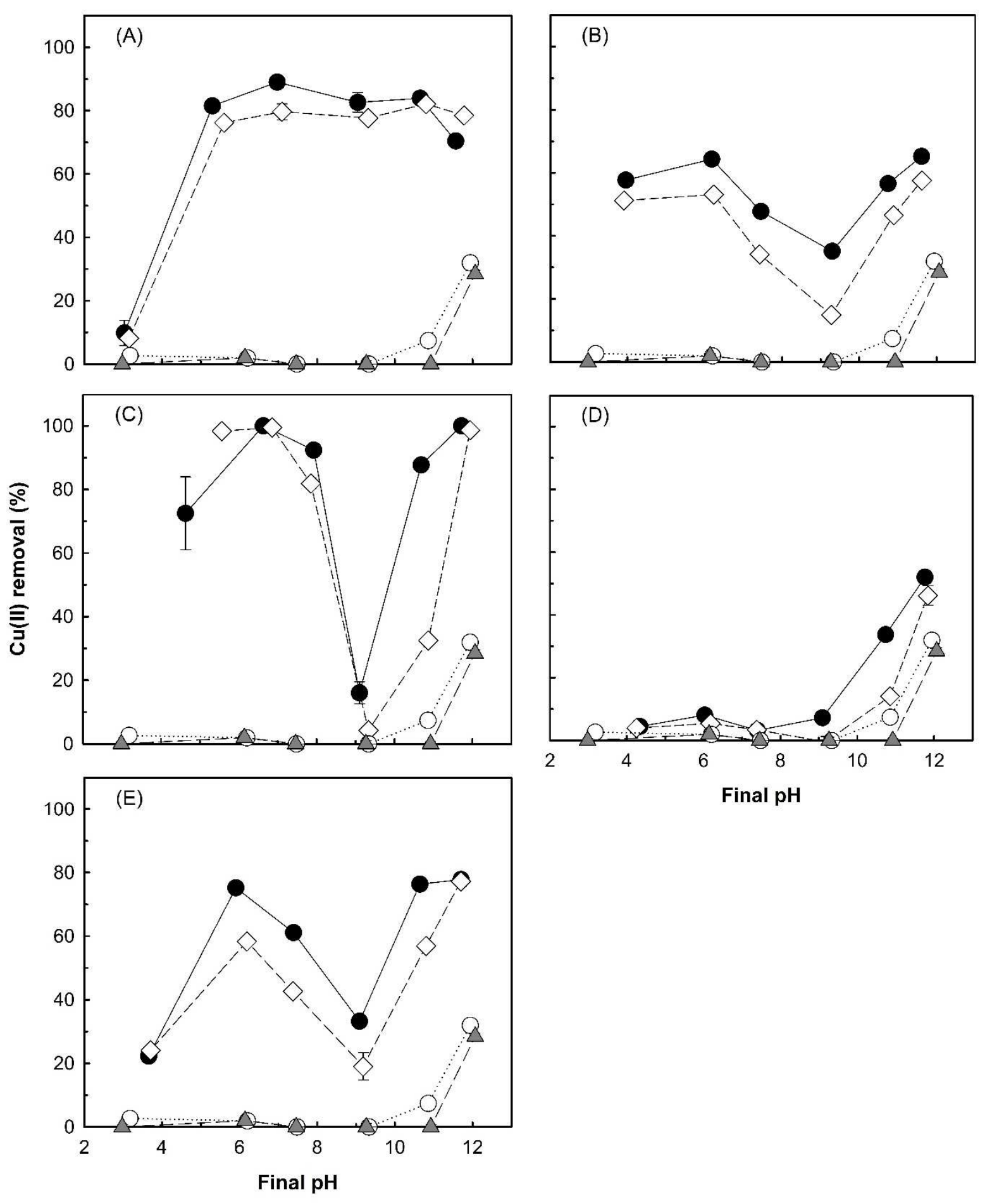

Fig. 2. Effect of $\mathrm{pH}$ on the $\mathrm{Cu}(\mathrm{II})$ removal efficiencies of (A) PC, (B) FS, (C) CT, (D) SSBC500, and (E) LRD in the presence of $(\bullet) 1 \mathrm{M}$ and $(\diamond) 2 \mathrm{M} \mathrm{NH}_{3}$. $\mathrm{Cu}(\mathrm{II})$ removal by the control samples at (०) $1 \mathrm{M}$ and ( $\Delta$ ) $2 \mathrm{M} \mathrm{NH}_{3}$ were also indicated. Experimental conditions: $5 \mathrm{mM} \mathrm{Cu}(\mathrm{II}), 100$ $\mathrm{mL} \mathrm{g}^{-1} \mathrm{~L} / \mathrm{S}$ ratio, $\mathrm{RT}\left(20 \pm 2{ }^{\circ} \mathrm{C}\right), 24 \mathrm{~h}$ contact time. Note: The straight lines were added for visual clarity only. 
At $\mathrm{pH} 3$, low $\mathrm{Cu}(\mathrm{II})$ removal efficiencies $(<25 \%)$ were observed for PC, SSBC500, and LRD (Figs. 2A, 2D and 2E), which could be due to electrostatic repulsion between the predominant $\mathrm{Cu}^{2+}$ (Fig. A.2) and the positively charged biosorbents surface as suggested by their pHPZC (Table A.1). FS and CT achieved relatively high removal efficiencies (> 50\%) at pH 3 (Figs. 2B and 2C), possibly because of the deprotonation of some functional groups specific for these biosorbents. FS contains sulfonic acid surface groups as shown by the FTIR analysis (Table A.2). These functional groups dissociate to form negatively charged sulfonate groups when $\mathrm{pH}$ is higher than its $\mathrm{pK}_{\mathrm{a}}$ of 0.5 (van Loon et al., 1993).

At pH 6, CT showed the highest $\mathrm{Cu}(\mathrm{II})$ removal of $100 \%$ (Fig. 2C), but this could have been influenced by its relatively higher final $\mathrm{pH}$ of 6.7 compared to those of the other biosorbents. FS, CT, and LRD achieved their highest $\mathrm{Cu}$ (II) removal efficiencies at around $\mathrm{pH} 6$, where the sum of the fractions of the major species $\mathrm{Cu}\left(\mathrm{NH}_{3}\right)^{2+}, \mathrm{Cu}\left(\mathrm{NH}_{3}\right)_{2}{ }^{2+}$, and $\mathrm{Cu}\left(\mathrm{NH}_{3}\right)_{3}{ }^{2+}$ reaches its maximum (Fig. A.2). Baba et al. (1984) observed a similar trend as $\mathrm{Cu}(\mathrm{II})$ adsorption from ammoniacal solutions on silica gel increased until $\mathrm{pH}$ 6, and then decreased thereafter.

At $\mathrm{pH}$ 7.5, the removal efficiencies of FS, CT, and LRD started to decrease by 7.7-18.9\%, while that of $\mathrm{PC}$ remained almost constant. At $\mathrm{pH} 9$, most biosorbents reached their minimum $\mathrm{Cu}$ (II) removal efficiencies $(<35 \%)$, except PC which achieved $82.6 \%\left(1 \mathrm{M} \mathrm{NH}_{3}\right)$ and $77.7 \%$ (2 $\mathrm{M} \mathrm{NH}_{3}$ ) (Fig. 2A) indicating further that $\mathrm{Cu}-\mathrm{NH}_{3}$ adsorption on $\mathrm{PC}$ is less $\mathrm{pH}$-dependent compared to the other biosorbents. Fuerstenau and Osseo-Asare (1987) also reported minimum $\mathrm{Cu}$ (II) adsorption on hematite at $\mathrm{pH} 9.25$ after reaching a maximum at $\mathrm{pH} 7 . \mathrm{Cu}\left(\mathrm{NH}_{3}\right)_{4}{ }^{2+}$ is the predominant $\mathrm{Cu}$ (II) species at $\mathrm{pH}$ 9. The $\mathrm{Cu}$ (II) ion has six coordination sites: two axial sites and four sites in the square plane for the attachment of up to four $\mathrm{NH}_{3}$ ligands. In the complexes $\mathrm{Cu}\left(\mathrm{NH}_{3}\right)^{2+}, \mathrm{Cu}\left(\mathrm{NH}_{3}\right)_{2}{ }^{2+}$, and $\mathrm{Cu}\left(\mathrm{NH}_{3}\right)_{3}{ }^{2+}$, two axial sites and at least one site in the square plane are available, whereas in $\mathrm{Cu}\left(\mathrm{NH}_{3}\right)_{4}{ }^{2+}$, only the two axial sites are available (Sharma et al., 2011). This suggests that $\mathrm{Cu}-\mathrm{NH}_{3}$ complexes with at least one free coordination site in the square plane 
are more favorably adsorbed. This is in accordance with the study of Tominaga et al. (1975), in which electron spin resonance spectroscopy revealed that the $\mathrm{Cu}$ species adsorbed on silica gel from an ammoniacal solution were neither $\mathrm{Cu}^{2+}$ nor $\mathrm{Cu}\left(\mathrm{NH}_{3}\right)_{4}{ }^{2+}$, but $\mathrm{Cu}\left(\mathrm{NH}_{3}\right)_{\mathrm{n}}{ }^{2+}(\mathrm{n}=1-3)$. While minimum $\mathrm{Cu}(\mathrm{II})$ removal at around $\mathrm{pH} 9$ has been previously reported, the consistent $\mathrm{Cu}$ (II) removal potential of PC between $\mathrm{pH} 5$ and 12 has not been reported to date and clearly holds an advantage over other biosorbents for its application towards a broader spectrum of ammoniacal Cu-bearing wastes.

In general, the highest $\mathrm{Cu}(\mathrm{II})$ adsorption in the basic $\mathrm{pH}$ range 9-12 was achieved at $\mathrm{pH} 11$ considering the removal observed in the control at $\mathrm{pH} 12$ (i.e., $33 \%$ at $1 \mathrm{M} \mathrm{NH}_{3}$ and $29 \%$ at 2 $\mathrm{M} \mathrm{NH}$ ). This could be due to the hydroxide ligand(s) present in the predominant hydroxyammine $\mathrm{Cu}$ complexes (Fig. A.2). The extent of drop and rebound is different for each biosorbent suggesting that it is dependent on the biosorbent characteristics. Crawford et al. (1997) observed this in a similar system and noted that the hydroxide ligand is essential to metal ion adsorption as it can participate in chemical interaction (e.g., hydrogen bonding) with the adsorbent surface.

\subsection{Kinetics of $\mathrm{Cu}(\mathrm{II})$ biosorption in the presence of $\mathrm{NH}_{3}$}

The results in Figs. 1 and 2 showed that within the typical $\mathrm{pH}$ range of ammoniacal waste streams (i.e., $\mathrm{pH}$ 9-12), the optimum $\mathrm{Cu}(\mathrm{II})$ removal efficiency without the influence of precipitation can be achieved at $\mathrm{pH} 11$. Hence, kinetic experiments were performed at $\mathrm{pH} 11$ to determine the rate of $\mathrm{Cu}(\mathrm{II})$ adsorption. Equilibrium was attained within $30 \mathrm{~min}$ in the case of FS, CT, and LRD, $1 \mathrm{~h}$ in PC, and $8 \mathrm{~h}$ in SSBC500 (Fig. 3). Rapid initial adsorption was observed for FS, CT, and LRD (48-75\%), followed by a slow increase over 16 hours. PC showed the highest $\mathrm{Cu}(\mathrm{II})$ removal efficiency $(75 \%)$ after a 15 -min contact time. Like in the case of SSBC500, slow adsorption of some metal-ammine complexes including $\mathrm{Cu}-\mathrm{NH}_{3}$ was 
previously reported to be caused by chemical changes in the adsorbed layer following the initial adsorption of the complex ion, rather than to a low adsorption rate (Smith, 1939).

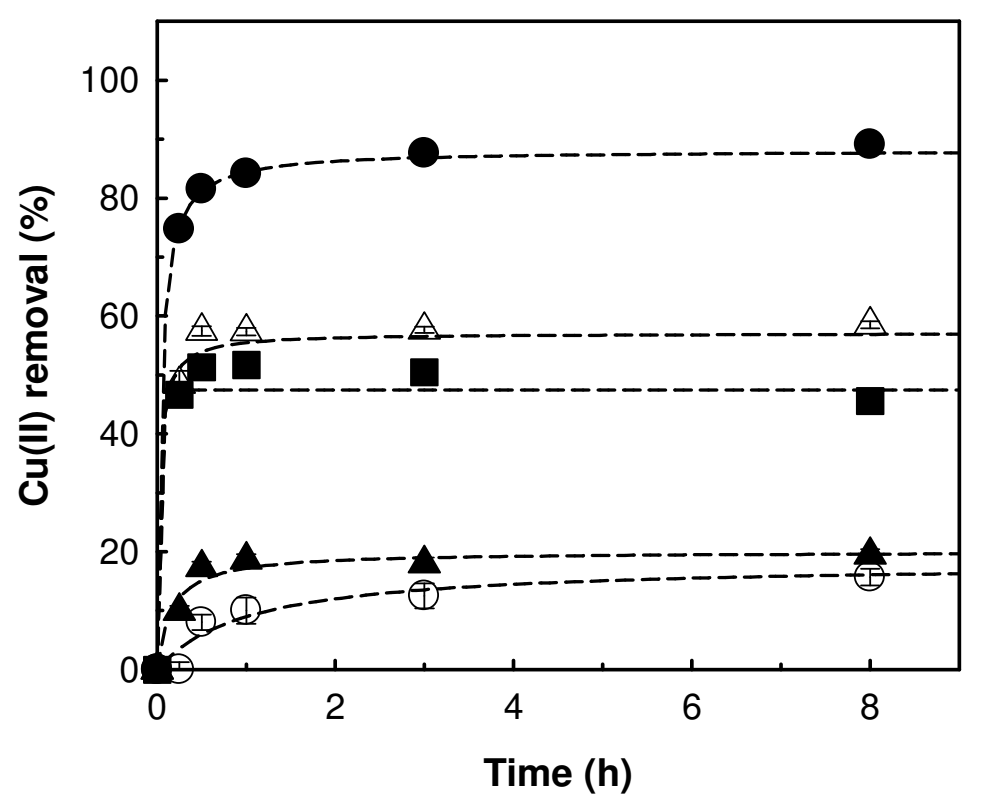

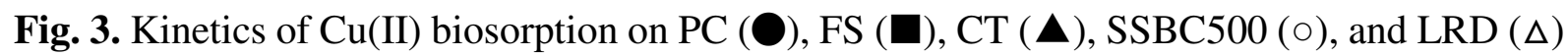
in ammoniacal solution. Experimental conditions: $5 \mathrm{mM} \mathrm{Cu}$ (II), $2 \mathrm{M} \mathrm{NH}_{3}, 100 \mathrm{~mL} \mathrm{~g}^{-1} \mathrm{~L} / \mathrm{S}$ ratio, $\mathrm{pH} 11, \mathrm{RT}\left(20 \pm 2{ }^{\circ} \mathrm{C}\right)$.

\subsection{Biosorption isotherms}

The adsorption equilibrium provides information about the affinity of the adsorbent for the adsorbate, and its distribution in the liquid and solid phase (Lodeiro et al., 2008). The equilibrium data of the biosorbents were fitted to the Langmuir and Freundlich isotherm models (Fig. A.3). Table 2 shows the constants and correlation coefficients $\left(\mathrm{R}^{2}\right)$ from the fittings of these models. PC obtained the highest Langmuir adsorption equilibrium constant $(b)$ of 1.101 $\mathrm{L} \mathrm{mmol}^{-1}$, indicating that it has more affinity for $\mathrm{Cu}$ compared to the other biosorbents. 
1 Table 2. Constants and correlation coefficients of Langmuir and Freundlich models for $\mathrm{Cu}(\mathrm{II})$ biosorption in the presence of $\mathrm{NH}_{3}$ using $\mathrm{PC}$, $\mathrm{FS}$,

$2 \mathrm{CT}$, SSBC500, and LRD. Experimental conditions: $2 \mathrm{M} \mathrm{NH}_{3}, 100 \mathrm{~mL} \mathrm{~g}^{-1} \mathrm{~L} / \mathrm{S}$ ratio, $\mathrm{pH} 11, \mathrm{RT}\left(20 \pm 2{ }^{\circ} \mathrm{C}\right), 24 \mathrm{~h}$ contact time.

\begin{tabular}{|c|c|c|c|c|c|c|c|c|c|c|c|c|}
\hline \multirow{3}{*}{ Biosorbent } & \multicolumn{6}{|c|}{ Without Zn(II) } & \multicolumn{6}{|c|}{ With 5 mM Zn(II) } \\
\hline & \multicolumn{3}{|c|}{ Langmuir model } & \multicolumn{3}{|c|}{ Freundlich model } & \multicolumn{3}{|c|}{ Langmuir model } & \multicolumn{3}{|c|}{ Freundlich model } \\
\hline & $R^{2}$ & $\begin{array}{c}b \\
\left(\mathbf{L} \text { mmol }^{-1}\right)\end{array}$ & $\underset{\left(\mathbf{m m o l} \mathbf{g}^{-1}\right)}{q_{\max }}$ & $R^{2}$ & $\begin{array}{c}K_{\mathbf{f}}\left(\left(\mathrm{mmol} \mathrm{g}^{-1}\right)(\mathbf{L}\right. \\
\left.\left.\mathbf{m m o l}^{-1}\right)^{1 / n}\right)\end{array}$ & $n$ & $R^{2}$ & $\begin{array}{c}b \\
\left(\mathrm{~L} \mathrm{mmol}^{-1}\right)\end{array}$ & $\underset{\left(\operatorname{mmol~g}^{-1}\right)}{q_{\max }}$ & $R^{2}$ & $\begin{array}{c}K_{\mathbf{f}}\left(\left(\mathrm{mmol} \mathrm{g}^{-1}\right)(\mathrm{L}\right. \\
\left.\left.\mathrm{mmol}^{-1}\right)^{1 / n}\right)\end{array}$ & $n$ \\
\hline $\mathrm{PC}$ & 0.988 & 1.101 & 0.94 & 0.765 & 0.528 & 7.30 & 0.966 & 0.548 & 1.07 & 0.793 & 0.239 & 3.47 \\
\hline FS & 0.937 & 0.142 & 0.91 & 0.793 & 0.239 & 3.47 & 0.987 & 0.040 & 1.14 & 0.945 & 0.118 & 2.16 \\
\hline $\mathrm{CT}$ & 0.967 & 0.059 & 2.03 & 0.885 & 0.235 & 2.19 & 0.963 & 0.006 & 2.34 & 0.951 & 0.019 & 1.20 \\
\hline SSBC500 & 0.944 & 0.089 & 0.30 & 0.820 & 0.063 & 3.04 & 0.968 & 0.066 & 0.27 & 0.886 & 0.046 & 2.69 \\
\hline LRD & 0.989 & 0.186 & 0.87 & 0.885 & 0.266 & 3.81 & 0.996 & 0.077 & 0.84 & 0.939 & 0.157 & 2.79 \\
\hline
\end{tabular}


The maximum $\mathrm{Cu}(\mathrm{II})$ adsorption capacities $\left(q_{\max }\right)$ of the biosorbents at a final $\mathrm{pH}$ of 11 were determined from the Langmuir model (Table 2). The order of $q_{\max }\left(\mathrm{mmol} \mathrm{g}^{-1}\right)$ follows: CT (2.03) $>$ PC (0.94) > FS $(0.91)>\operatorname{LRD}(0.87)>\operatorname{SSBC500}(0.30)$. These $q_{\max }$ values are of the same order of magnitude as those of some adsorbents reported in the literature. However, the differences in the adsorption systems used should be compared to evaluate the reported $q_{\text {max }}$ objectively. For instance, silica gel has a $\mathrm{Cu} q_{\max }$ of $2 \mathrm{mmol} \mathrm{g}^{-1}$ at $\mathrm{pH} 6$ in the presence of $6 \mathrm{M}$ $\mathrm{NH}_{3}$ (Smith and Jacobson, 1956). Graphite oxide (GO) has a $\mathrm{Cu} q_{\max }$ of $22 \mathrm{mmol} \mathrm{g}^{-1}$ in a system with 0.6 $\mathrm{M} \mathrm{NH}_{3}$ and $\mathrm{pH} 11.2$ (Kovtjukhova and Karpenko, 1992). This $q_{\max }$ is higher by at least 14 times than those of the biosorbents used in this study, however, GO was not used in aqueous systems with much higher $\mathrm{NH}_{3}$ concentrations. Furthermore, the particle sizes of GO can be as small as $0.1 \mu \mathrm{m}$ (Taha-Tijerina et al., 2015), which are difficult to separate from the solution after adsorption. Lastly, the synthesis of GO involves oxidation with $\mathrm{KMnO}_{4}$ in concentrated $\mathrm{H}_{2} \mathrm{SO}_{4}$, making this material expensive and unsustainable.

\subsection{Competition and selectivity between $\mathrm{Cu}(\mathrm{II})$ and $\mathrm{Zn}(\mathrm{II})$}

Single metal systems rarely occur in real waste streams, making it important to evaluate the biosorbents in a competitive metal adsorption process. Since $\mathrm{Cu}(\mathrm{II})$ and $\mathrm{Zn}(\mathrm{II})$ coexist in the real leachate under study and other process and waste streams (e.g., electroplating wastewater), their adsorption characteristics in a binary metal system at equimolar concentrations (i.e., 50 $\mathrm{mM}$ ) were investigated (Fig. 4). The $\mathrm{Cu}$ (II) adsorption capacity $\left(q_{C u}\right)$ of PC slightly increased by $0.07 \mathrm{mmol} \mathrm{g}^{-1}$ when $50 \mathrm{mM} \mathrm{Zn(II)} \mathrm{was} \mathrm{present,} \mathrm{indicating} \mathrm{different} \mathrm{sorption} \mathrm{sites} \mathrm{for} \mathrm{Cu}$ and Zn. For the other biosorbents, FS, CT, SSBC500 and LRD, a decrease in $q_{C u}$ was observed, but to variable degrees $\left(0.03-0.89 \mathrm{mmol} \mathrm{g}^{-1}\right.$, Fig. 4). In the case of FS, competition was almost equivalent, with a $q_{C u}$ of $0.36 \mathrm{mmol} \mathrm{g}{ }^{-1}$ and $q_{Z n}$ of $0.30 \mathrm{mmol} \mathrm{g}{ }^{-1}$. For CT, $q_{C u}$ of $1.47 \mathrm{mmol} \mathrm{g}^{-1}$ decreased to $0.58 \mathrm{mmol} \mathrm{g}^{-1}$, although $q_{\mathrm{Zn}}$ was only $0.13 \mathrm{mmol} \mathrm{g} \mathrm{g}^{-1}$, indicating that one mole of $\mathrm{Zn}$ interacts with more functional groups than one mole of $\mathrm{Cu}$. Multidentism could be the 
binding mechanism of $\mathrm{Zn}$ (II) to $\mathrm{CT}$, which implies that more than one acidic group on the surface of CT was involved in binding to a single Zn ion (Lodeiro et al., 2008).

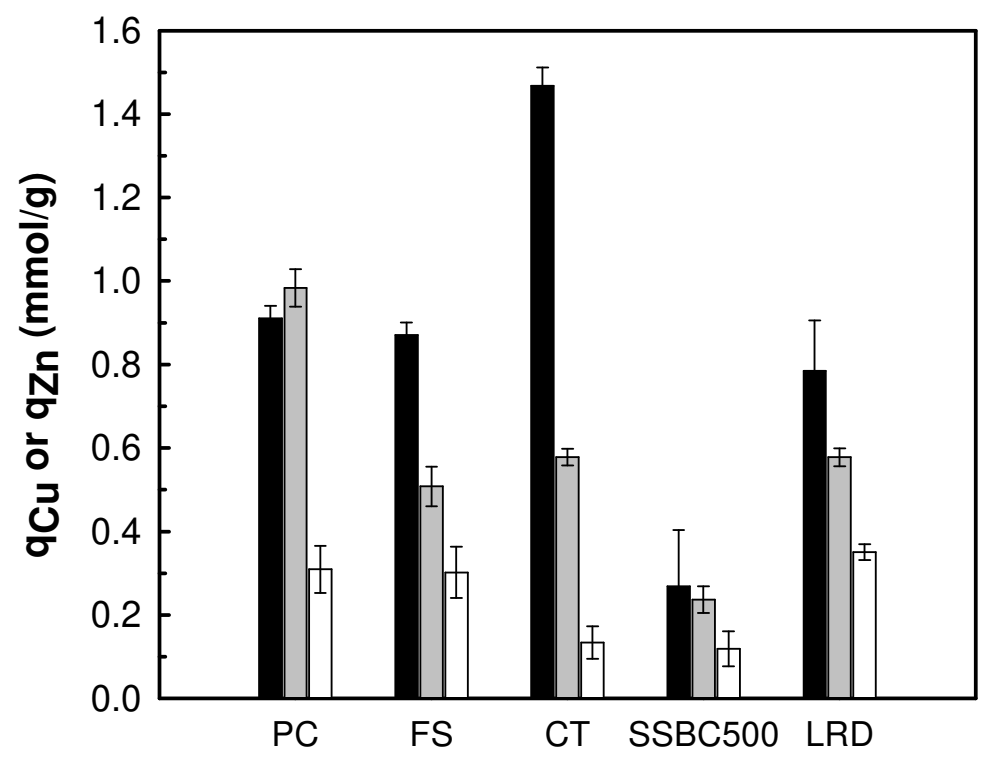

Fig. 4. $\mathrm{Cu}(\mathrm{II})(\square)$ and $\mathrm{Zn}(\mathrm{II})$ ( $\square$ ) adsorption capacities of PC, FS, CT, SSBC500, and LRD in binary metal solutions containing $\mathrm{NH}_{3}$. The $\mathrm{Cu}(\mathrm{II})$ adsorption capacities of the biosorbents in single metal ammoniacal solutions ( $\mathbf{n})$ are also shown in this figure for reference. Experimental conditions: $50 \mathrm{mM} \mathrm{Cu(II),} 0 \mathrm{mM} \mathrm{Zn}$ (II) (single metal solution) or $50 \mathrm{mM} \mathrm{Zn}$ (II) (binary metal solution), $2 \mathrm{M} \mathrm{NH}_{3}, 100 \mathrm{~mL} \mathrm{~g}^{-1} \mathrm{~L} / \mathrm{S}$ ratio, $\mathrm{pH} 11, \mathrm{RT}\left(20 \pm 2{ }^{\circ} \mathrm{C}\right), 24 \mathrm{~h}$ contact time.

Despite the decrease in $q_{C u}$, all biosorbents exhibited higher affinity for $\mathrm{Cu}(\mathrm{II})-\mathrm{NH}_{3}$ complexes than $\mathrm{Zn}(\mathrm{II})-\mathrm{NH}_{3}$ complexes (Fig. 4). The selectivity quotients $\left(K_{C u / Z n}\right)$ support the higher affinity for $\mathrm{Cu}-\mathrm{NH}_{3}$ considering that all values are greater than $1-\mathrm{PC}$ (3.97), FS (1.85), CT (4.98), SSBC500 (2.14), and LRD (1.84). This finding contrasts with the results of Kar et al. (1975) where hydrous $\beta-\mathrm{SnO}_{2}$ was more selective for $\mathrm{Zn}(\mathrm{II})-\mathrm{NH}_{3}$ over $\mathrm{Cu}-\mathrm{NH}_{3}$ at $\mathrm{pH} 8.5$. However, the selectivity quotient $K_{Z n / C u}$ decreased from 2.41 to 1.08 as the equimolar concentrations of $\mathrm{Zn}(\mathrm{II})$ and $\mathrm{Cu}(\mathrm{II})$ increased from 0.01 to $0.15 \mathrm{M}$.

The results of the present study and those of Kar et al. (1975) suggest that the speciation of the $\mathrm{Cu}(\mathrm{II})-\mathrm{Zn}(\mathrm{II})-\mathrm{NH}_{3}$ system (Fig. A.4) could influence the biosorbents' selectivity. At pH 11, the predominant $\mathrm{Cu}$ (II) species were $\mathrm{Cu}\left(\mathrm{NH}_{3}\right)_{4}{ }^{2+}$ and $\mathrm{Cu}\left(\mathrm{NH}_{3}\right)_{3} \mathrm{OH}^{+}$in equal fractions, whereas 
for $\mathrm{Zn}(\mathrm{II})$, it was solely $\mathrm{Zn}\left(\mathrm{NH}_{3}\right)_{4}{ }^{2+}$. Mixed hydroxyammine metal complexes (e.g., $\left.\mathrm{Cu}\left(\mathrm{NH}_{3}\right)_{3} \mathrm{OH}^{+}\right)$have higher possibility of being adsorbed because of the presence of at least one hydroxide ligand. Additional experiments showed that $\mathrm{Cu}(\mathrm{II})$ was still preferentially adsorbed over $\mathrm{Zn}$ (II) at pH 9 (Fig. A.5), despite both $\mathrm{Cu}(\mathrm{II})$ and $\mathrm{Zn}$ (II) tetraammine complexes form at this $\mathrm{pH}$. Thus, aside from metal speciation, the complex ion orientation on the biosorbent surface could have affected the adsorption. The number of hydrogens that are spaced properly to form hydrogen bonds with the biosorbent surface oxygen atoms is important in complex ion adsorption (Smith and Jacobson, 1956). It is possible that the $\mathrm{Cu}(\mathrm{II})$-ammine complexes attached to the biosorbent surface on their edge, resulting in more available adsorption sites, and thus, higher amounts of $\mathrm{Cu}(\mathrm{II})$-ammine complex adsorbed.

The $q_{\max }$ of the biosorbents for $\mathrm{Cu}(\mathrm{II})$ were also re-evaulated in the presence of $\mathrm{Zn}$ (II). Similar to the previous $q_{\max }$ determination, a better fit of the equilibrium data of all biosorbents was obtained using the Langmuir model (Table 2). With $5 \mathrm{mM} \mathrm{Zn(II)} \mathrm{present,} \mathrm{the} \mathrm{order} \mathrm{of} q_{\max }$ $\left(\mathrm{mmol} \mathrm{g}^{-1}\right)$ changed to: CT (2.34) > FS (1.14) > PC (1.07) > LRD (0.84) > SSBC500 (0.27) The $q_{\max }$ of PC, FS, and CT for $\mathrm{Cu}(\mathrm{II})$ increased by $0.13,0.23$, and $0.31 \mathrm{mmol} \mathrm{g}^{-1}$, respectively. The increase in the $q_{\max }$ of PC was expected considering that the $q_{C u}$ of PC increased despite the presence of $50 \mathrm{mM} \mathrm{Zn(II)} \mathrm{in} \mathrm{the} \mathrm{system} \mathrm{(Fig.} \mathrm{4).}$

\subsection{Effect of carbonate on $\mathrm{Cu}(\mathrm{II})$ biosorption from ammoniacal solution}

The leachate from ASR extraction contains $\mathrm{CO}_{3}{ }^{2-}$, and thus, its effect on $\mathrm{Cu}$ (II) biosorption was investigated in systems containing $5 \mathrm{mM} \mathrm{Cu}(\mathrm{II}), 2 \mathrm{M} \mathrm{NH}_{3}$, and $1 \mathrm{M} \mathrm{CO}_{3}{ }^{2-}$ at $\mathrm{pH} 9$ and 11 . Generally, $\mathrm{Cu}$ (II) removal by all biosorbents decreased in the presence of $\mathrm{CO}_{3}{ }^{2-}$ (Fig. 5) with the decrease being more pronounced $(\sim 30 \%)$ at $\mathrm{pH} 11$ for FS, CT and LRD. $\mathrm{Cu}$ (II) removal by PC also decreased, but it still achieved $68.6 \%$ removal. At $\mathrm{pH} 9$, the decrease in $\mathrm{Cu}$ (II) removal efficiencies of most biosorbents was minimal, except that of PC, which decreased by $20.7 \%$. Despite the presence of $1 \mathrm{M} \mathrm{CO}_{3}{ }^{2-}$, the predominant $\mathrm{Cu}$ (II) species remain as $\mathrm{Cu}\left(\mathrm{NH}_{3}\right)_{4}{ }^{2+}(\mathrm{pH}$ 
9) and a mix of $\mathrm{Cu}\left(\mathrm{NH}_{3}\right)_{4}{ }^{2+}$ and $\mathrm{Cu}\left(\mathrm{NH}_{3}\right)_{3} \mathrm{OH}^{+}$(pH 11) (Fig. A.6). Thus, the decrease in adsorption cannot be attributed to alteration of $\mathrm{Cu}(\mathrm{II})$ speciation, but rather likely due to the high amount of $\mathrm{CO}_{3}{ }^{2-}$ in the system. There have been reports regarding possible enhancement of metal and nonmetal adsorption in the presence of low $\mathrm{CO}_{3}{ }^{2-}$ concentrations through the formation of extra reactive sites coexisting with the adsorbed $\mathrm{CO}_{3}{ }^{2-}$ (Villalobos et al., 2001; Wijnja and Schulthess, 2002). However, at much higher $\mathrm{CO}_{3}{ }^{2-}$ concentrations, steric interactions may occur, leading to decreased metal adsorption (LaFlamme and Murray, 1987; Wijnja and Schulthess, 2002). The difference between the adsorption performances of the biosorbents could thus be due to $\mathrm{CO}_{3}{ }^{2-}$ speciation (Fig. A.6). 

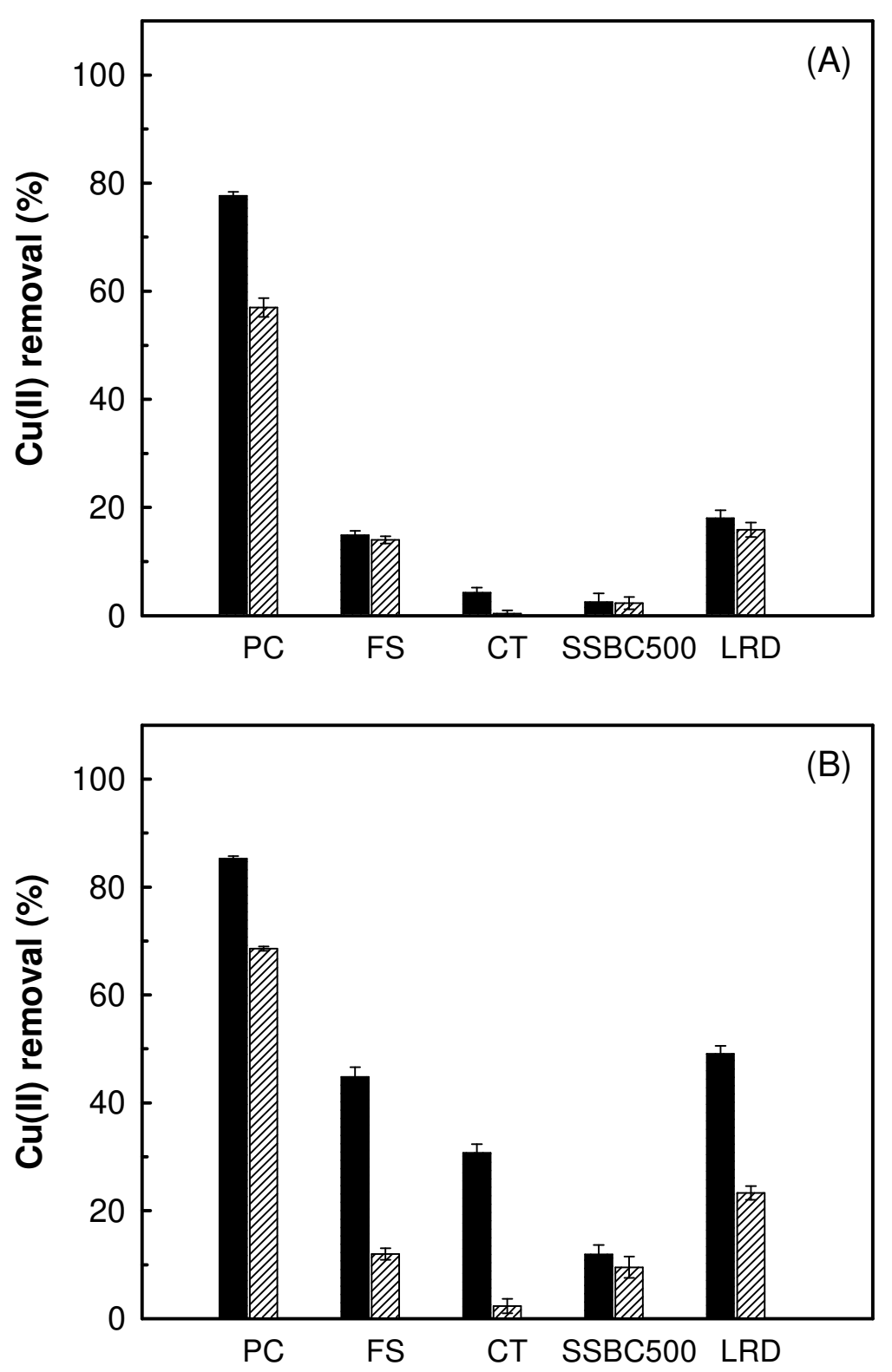

Fig. 5. $\mathrm{Cu}$ (II) removal of PC, FS, CT, SSBC500, and LRD from ammoniacal solution in the absence ( $($ ) and presence ( $)$ of $\mathrm{CO}_{3}{ }^{2-}$ at (A) $\mathrm{pH} 9$ and (B) $\mathrm{pH}$ 11. Experimental conditions: 5 $\mathrm{mM} \mathrm{Cu}(\mathrm{II}), 2 \mathrm{M} \mathrm{NH}_{3}, 1 \mathrm{M} \mathrm{CO}_{3}{ }^{2-}, 100 \mathrm{~mL} \mathrm{~g}^{-1} \mathrm{~L} / \mathrm{S}$ ratio, $\mathrm{RT}\left(20 \pm 2{ }^{\circ} \mathrm{C}\right), 24 \mathrm{~h}$ contact time.

\section{7. $\mathrm{Cu}(\mathrm{II})$ biosorption from real $\mathrm{Cu}-\mathrm{NH}_{3}$ leachates}

The biosorbents were tested for their performance with a real leachate ( $\mathrm{pH}$ 11.1) containing $6 \mathrm{mM} \mathrm{Cu}(\mathrm{II}), 1.1 \mathrm{mM} \mathrm{Zn(II),} 1 \mathrm{M} \mathrm{NH}_{3}$, and $0.5 \mathrm{M} \mathrm{CO}_{3}{ }^{2-}$ (Williamson et al., 2020). A simplified synthetic leachate with approximately the same composition was prepared as a reference and to highlight any other factors that impact biosorption. The $\mathrm{Cu}(\mathrm{II})$ removal 
efficiencies of the biosorbents used in the real leachate broadly matched the synthetic leachate (Fig. 6). The slight decrease $(<5 \%)$ in $\mathrm{Cu}(\mathrm{II})$ removal could be partially accounted to slightly higher initial $\mathrm{Cu}(\mathrm{II})$ concentration of the real leachate, or other uncharacterized organic/inorganic species that occurred during the leaching process. The results suggest that the performances of the biosorbents are comparable when used in both types of leachate, hence, validating that the results obtained in the previous sections are representative for real leachates. PC achieved the highest $\mathrm{Cu}(\mathrm{II})$ removal efficiency of $69.4 \%$ despite the presence of ligands and other ions in the real leachate. All other biosorbents achieved $<30 \% \mathrm{Cu}$ (II) removal efficiencies.

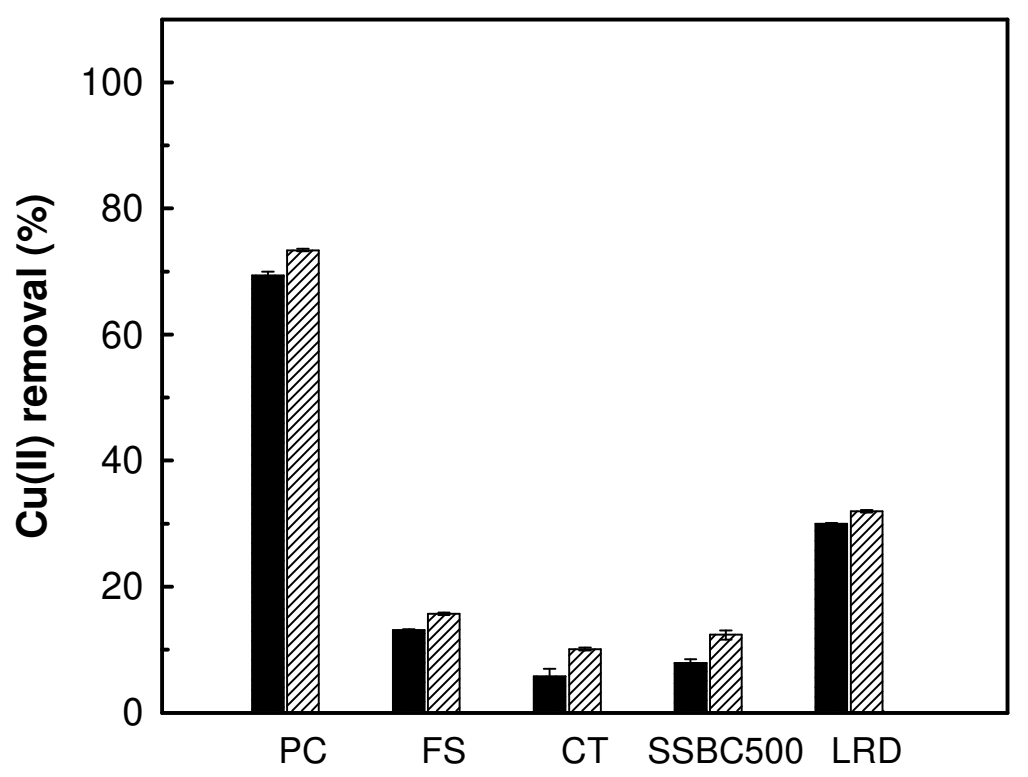

Fig. 6. $\mathrm{Cu}(\mathrm{II})$ removal efficiencies of PC, FS, CT, SSBC500, and LRD in real (匹) and synthetic leachates (ख). Experimental conditions: $6 \mathrm{mM} \mathrm{Cu}(\mathrm{II}), 1.1 \mathrm{mM} \mathrm{Zn}(\mathrm{II}), 1 \mathrm{M} \mathrm{NH}_{3}, 0.5 \mathrm{M} \mathrm{CO}_{3}{ }^{2-}$, $100 \mathrm{~mL} \mathrm{~g}^{-1} \mathrm{~L} / \mathrm{S}$ ratio, $\mathrm{pH} 11, \mathrm{RT}\left(20 \pm 2{ }^{\circ} \mathrm{C}\right), 24 \mathrm{~h}$ contact time.

Exhibiting an exceptional adsorption performance, $\mathrm{PC}$ has the potential to remediate $\mathrm{Cu}$ $\mathrm{NH}_{3}$ waste streams and subsequently recover $\mathrm{Cu} . \mathrm{PC}$ is a tannin-rich material containing pyrogallol B-rings with three adjacent -OH groups (Gandini, 1989; Oo et al., 2009). Previous studies have shown that a part of the phenolic - $\mathrm{OH}$ groups of tannins could be converted into $\mathrm{NH}_{2}$ functions by amination (Hashida et al., 2009; Arbenz and Avérous, 2015). In the case of 
tannins with pyrogallol B-rings, $\mathrm{NH}_{3}$ treatment in the presence of $\mathrm{O}_{2}$ produces 4'-amino-3',5'dihydroxybenzene on the B-ring under relatively mild conditions without a catalyst (Hashida et al., 2009). With excess $\mathrm{NH}_{3}$ in the solution, it is probable that amination of the pyrogallol Brings of $\mathrm{PC}$ occurred. The adsorption of $\mathrm{Cu}^{-\mathrm{NH}_{3}}$ complexes onto PC likely occurred via a combination of two mechanisms-coordination with the $-\mathrm{NH}_{2}$ functional groups and electrostatic attraction between the positively charged $\mathrm{Cu}-\mathrm{NH}_{3}$ complexes and the net negative surface charge of $\mathrm{PC}$ at $\mathrm{pH}>5.06(\mathrm{pH} \mathrm{PZC})$ caused by the dissociation of O-containing surface groups. X-ray photoelectron spectroscopy (XPS) results (Fig. A.7) show that Cu2p peak (933.1 $\mathrm{eV}$ ) was detected in the $\mathrm{Cu}$-adsorbed $\mathrm{PC}$ aside from the characteristic peaks $\mathrm{C} 1 \mathrm{~s}, \mathrm{~N} 1 \mathrm{~s}$, and $\mathrm{O} 1 \mathrm{~s}$ of raw PC. Additionally, the O1s peak shifted from $533.1 \mathrm{eV}$ to $532.0 \mathrm{eV}$ after $\mathrm{Cu}$ (II) adsorption, while the N1s peak shifted from $400.4 \mathrm{eV}$ to $398.7 \mathrm{eV}$ and increased in intensity. These results indicate that $\mathrm{N}$ - and O-containing surface groups (Fig. A.7) were responsible for $\mathrm{Cu}(\mathrm{II})$ adsorption.

\subsection{Pinecone as a potential $\mathrm{Cu}(\mathrm{II})$ biosorbent from $\mathrm{Cu}-\mathrm{NH}_{3}$ waste streams}

Pinecones are considered as a forest residue, which further strengthens the need to utilize it as a viable and sustainable biosorbent for $\mathrm{Cu}(\mathrm{II})$ removal from leachates and wastewater. The worldwide forest plantation area of Pinus species amounts to 37.4 million ha (Osman, 2013). Assuming that pinecones from 3 to 5 million ha would be harvested annually, with an average yield of $1200 \mathrm{~kg} / \mathrm{ha}$ (Aniszewska et al., 2018), the annual harvest would amount to 3.6 to 6 million tons of pinecones. The collection of pinecones can present a drawback, but then largescale collection should be introduced at some point considering the impacts of pinecones on the nutrients and regeneration of forest stands (Aniszewska et al., 2018).

To further enhance the sustainability of this process, subsequent investigations are needed to recover the adsorbed $\mathrm{Cu}$ (II) on pinecone. $\mathrm{Cu}$ (II) desorption from pinecone has been addressed in some studies, however, desorption needs to be carefully performed to maintain a balance between efficient $\mathrm{Cu}(\mathrm{II})$ up-concentration and pinecone condition preservation for the 
subsequent adsorption-desorption cycles (Ofomaja et al., 2010; Martín-Lara et al., 2016). Although a destructive process, combustion of the $\mathrm{Cu}(\mathrm{II})$-loaded pinecone is also a feasible option to recover $\mathrm{Cu}$. The objective of such approach is to obtain a $\mathrm{Cu}$-rich ash that could be subsequently processed in a metal processing plant (Fomina and Gadd, 2014). For this, it is important to determine the speciation of $\mathrm{Cu}$ to ensure it does not form volatile compounds during the decomposition process (Almendros et al., 2015).

\section{Conclusions}

Overall, this study has demonstrated that a top-down approach to biosorbent selection can efficiently highlight an optimal biosorbent for a particular complex waste stream. From the screen of 23 biosorbents under varying $\mathrm{pH}, \mathrm{NH}_{3}, \mathrm{Zn}$ and $\mathrm{CO}_{3}{ }^{2-}$ concentrations, key biosorbents were identified as PC, FS, CT, SSBC500, and LRD. Within the typically observed pH range of ammoniacal waste streams (i.e., 9-12), the highest $\mathrm{Cu}$ (II) adsorption was obtained at $\mathrm{pH} 11$, while the minimum was observed at around $\mathrm{pH}$ 9, except for PC, which was identified as a high-performing and robust biosorbent with no marked loss in $\mathrm{Cu}(\mathrm{II})$ removal between $\mathrm{pH} 5$ and 12. $\mathrm{PC}$ was $\mathrm{Cu}$-selective even in the presence of $\mathrm{Zn}(\mathrm{II})$ and $\mathrm{CO}_{3}{ }^{2-}$.

$\mathrm{PC}$ is a natural and low-cost material, but it has proven its potential in adsorbing $\mathrm{Cu}(\mathrm{II})$ for possible $\mathrm{Cu}$ (II) recovery from the increasing volumes of complex $\mathrm{Cu}-\mathrm{NH}_{3}$ waste streams. Not only it promotes an eco-friendly approach and stability over large $\mathrm{pH}$ range relevant to treat $\left(\mathrm{NH}_{4}\right)_{2} \mathrm{CO}_{3}$ bearing effluents, but also provides a new route to recycle $\mathrm{Cu}$ for potential use in the metallurgical industries. This study demonstrated the potential of a fully integrated metal recovery technology (i.e., bioleaching followed by biosorption), which could be an effective approach to elemental sustainability. With the increasing environmental awareness of the scientific and engineering community, policymakers, and public in general, the advantages of biosorption are becoming more evident, making it more competitive than the existing technologies for $\mathrm{Cu}$ removal and recovery. 


\section{Acknowledgements}

The authors acknowledge Prof. Olivier De Clerck (UGent Phycology Laboratory) for helping with the collection of the macroalgae Fucus spiralis; Prof. Frederik Ronsse and Stef Ghysels (UGent Thermochemical Conversion of Biomass research group) for providing the lignin-rich digested stillage; and Prof. Loretta Li (UBC Environmental Engineering Group) for allowing us to use their laboratory for some of the experiments.

\section{Funding sources}

This work was supported by European Union's Horizon 2020 research and innovation program (METGROW+, grant number 690088) and UGent Special Research Fund (BOF).

\section{Appendix A. Supplementary Data}

The supplementary data of this work can be found in the online version of the paper. This document contains Texts A.1-A.3, Tables A.1-A.2 and Figs. A.1-A.7.

\section{References}

Al-Saydeh, S.A., El-Naas, M.H., Zaidi, S.J., 2017. Copper removal from industrial wastewater: A comprehensive review. J. Ind. Eng. Chem. 56, 35-44.

Almendros, A.I., Martín-Lara, M.A., Ronda, A., Pérez, A., Blázquez, G., Calero, M., 2015. Physico-chemical characterization of pine cone shell and its use as biosorbent and fuel. Bioresour. Technol. 196, 406-412.

Aniszewska, M., Gendek, A., Zychowicz, W., 2018. Analysis of Selected Physical Properties of Conifer Cones with Relevance to Energy Production Efficiency. Forests 9, 405-416. Arbenz, A., Avérous, L., 2015. Chemical modification of tannins to elaborate aromatic biobased macromolecular architectures. Green Chem. 17, 2626-2646.

Baba, Y., Ishikawa, M., Nakahara, S., Inoue, K., Nakamori, I., 1984. Adsorption Equilibrium of Copper and Cadmium on Silica Gel from Ammoniacal Solutions. Sep. Sci. Technol. 19, 417-427. 
Bailey, S.E., Olin, T.J., Bricka, R.M., Adrian, D.D., 1999. A review of potentially low-cost sorbents for heavy metals. Water Res. 33, 2469-2479.

Chai, L.-y., Peng, C., Min, X.-b., Tang, C.-j., Song, Y.-X., Zhang, Y., Zhang, J., Ali, M., 2017. Two-sectional struvite formation process for enhanced treatment of copper-ammonia complex wastewater. T Nonferr Metal Soc 27, 457-466.

Ciacci, L., Fishman, T., Elshkaki, A., Graedel, T.E., Vassura, I., Passarini, F., 2020. Exploring future copper demand, recycling and associated greenhouse gas emissions in the EU-28. Global Environ. Change 63, 102093.

Cojocaru, C., Diaconu, M., Cretescu, I., Savić, J., Vasić, V., 2009. Biosorption of copper(II) ions from aqua solutions using dried yeast biomass. Colloids Surf., A 335, 181-188. Crawford, R.J., Mainwaring, D.E., Harding, I.H., 1997. Adsorption and coprecipitation of heavy metals from ammoniacal solutions using hydrous metal oxides. Colloids Surf., A 126, 167-179.

Egenhofer, C., Schrefler, L., Rizos, V., Marcu, A., Genoese, F., Renda, A., Wieczorkiewicz, J., Roth, S., Infelise, F., Luchetta, G., Colantoni, L., Stoefs, W., Timini, J., Simonelli, F., 2014. Composition and Drivers of Energy Prices and Costs in Energy Intensive Industries: The Case of Ceramics, Flat Glass and Chemical Industries.

Elliott, H.A., Huang, C.P., 1979. The effect of complex formation on the adsorption characteristics of heavy metals. Environ. Int. 2, 145-155.

Fomina, M., Gadd, G.M., 2014. Biosorption: current perspectives on concept, definition and application. Bioresour. Technol. 160, 3-14.

Fu, F., Wang, Q., 2011. Removal of heavy metal ions from wastewaters: A review. J. Environ. Manage. 92, 407-418.

Fuerstenau, D.W., Osseo-Asare, K., 1987. Adsorption of copper, nickel, and cobalt by oxide adsorbents from aqueous ammoniacal solutions. J. Colloid Interface Sci. 118, 524-542. 
Gandini, A., 1989. 19 - Polymers From Renewable Resources. in: Allen, G., Bevington, J.C. (Eds.). Comprehensive Polymer Science and Supplements. Pergamon, Amsterdam, pp. 527573.

Garside, M., 2020. Global Copper Demand By Region 2012-2019.

Gerente, C., Lee, V.K.C., Cloirec, P.L., McKay, G., 2007. Application of Chitosan for the Removal of Metals From Wastewaters by Adsorption-Mechanisms and Models Review. Crit Rev Env Sci Tec 37, 41-127.

Ghysels, S., Ronsse, F., Dickinson, D., Prins, W., 2019. Production and characterization of slow pyrolysis biochar from lignin-rich digested stillage from lignocellulosic ethanol production. Biomass Bioenergy 122, 349-360.

Han, R., Zhang, L., Song, C., Zhang, M., Zhu, H., Zhang, L., 2010. Characterization of modified wheat straw, kinetic and equilibrium study about copper ion and methylene blue adsorption in batch mode. Carbohydr. Polym. 79, 1140-1149.

Hashida, K., Makino, R., Ohara, S., 2009. Amination of pyrogallol nucleus of condensed tannins and related polyphenols by ammonia water treatment. Holzforschung 63, 319-326. He, J., Chen, J.P., 2014. A comprehensive review on biosorption of heavy metals by algal biomass: Materials, performances, chemistry, and modeling simulation tools. Bioresour. Technol. 160, 67-78.

Hu, H., Li, X., Huang, P., Zhang, Q., Yuan, W., 2017. Efficient removal of copper from wastewater by using mechanically activated calcium carbonate. J. Environ. Manage. 203, 1-7. Inyang, M.I., Gao, B., Yao, Y., Xue, Y., Zimmerman, A., Mosa, A., Pullammanappallil, P., Ok, Y.S., Cao, X., 2016. A review of biochar as a low-cost adsorbent for aqueous heavy metal removal. Crit Rev Env Sci Tec 46, 406-433.

Kar, K.R., Pandeya, K.B., Bhaduri, A.K., 1976. Ion-exchange properties of hydrous ceric oxide-I: Sorption of some metal ammines. J. Inorg. Nucl. Chem. 38, 1211-1213. 
Kar, K.R., Srivastava, R.K., Bhushan, B., 1975. Sorption of certain metal ammine complexes on hydrous $\beta$-SnO2. J. Chin. Chem. Soc. 22, 151-156.

Kovtjukhova, N., Karpenko, G., 1992. The Interaction of Cu2+ Ammine Ions with Graphite Oxide. Mater. Sci. Forum 91-93, 219-223.

LaFlamme, B.D., Murray, J.W., 1987. Solidsolution interaction: The effect of carbonate alkalinity on adsorbed thorium. Geochim. Cosmochim. Acta 51, 243-250.

Lodeiro, P., Fuentes, A., Herrero, R., Sastre de Vicente, M.E., 2008. CrIII binding by surface polymers in natural biomass: the role of carboxylic groups. Environ. Chem. 5, 355-365. Martín-Lara, M.A., Blázquez, G., Calero, M., Almendros, A.I., Ronda, A., 2016. Binary biosorption of copper and lead onto pine cone shell in batch reactors and in fixed bed columns. Int. J. Miner. Process. 148, 72-82.

Meunier, N., Laroulandie, J., Blais, J.F., Tyagi, R.D., 2003. Cocoa shells for heavy metal removal from acidic solutions. Bioresour. Technol. 90, 255-263.

Murphy, V., Hughes, H., McLoughlin, P., 2007. Cu(II) binding by dried biomass of red, green and brown macroalgae. Water Research 41, 731-740.

Ofomaja, A.E., Naidoo, E.B., Modise, S.J., 2009. Removal of copper(II) from aqueous solution by pine and base modified pine cone powder as biosorbent. J. Hazard. Mater. 168, 909-917.

Ofomaja, A.E., Naidoo, E.B., Modise, S.J., 2010. Dynamic studies and pseudo-second order modeling of copper(II) biosorption onto pine cone powder. Desalination 251, 112-122. Oo, C.W., Kassim, M.J., Pizzi, A., 2009. Characterization and performance of Rhizophora apiculata mangrove polyflavonoid tannins in the adsorption of copper (II) and lead (II). Ind. Crops Prod. 30, 152-161.

Osman, K.T., 2013. Forest Soils: Properties and Management. Springer International Publishing, Switzerland. 
Otero, M., Rozada, F., Morán, A., Calvo, L.F., García, A.I., 2009. Removal of heavy metals from aqueous solution by sewage sludge based sorbents: competitive effects. Desalination 239, 46-57.

Pellera, F.-M., Giannis, A., Kalderis, D., Anastasiadou, K., Stegmann, R., Wang, J.-Y., Gidarakos, E., 2012. Adsorption of $\mathrm{Cu}(\mathrm{II})$ ions from aqueous solutions on biochars prepared from agricultural by-products. J. Environ. Manage. 96, 35-42.

Peng, C., Liu, Y., Bi, J., Xu, H., Ahmed, A.-S., 2011. Recovery of copper and water from copper-electroplating wastewater by the combination process of electrolysis and electrodialysis. J. Hazard. Mater. 189, 814-820.

Rahman, M.S., Islam, M.R., 2009. Effects of $\mathrm{pH}$ on isotherms modeling for $\mathrm{Cu}(\mathrm{II})$ ions adsorption using maple wood sawdust. Chem. Eng. J. 149, 273-280.

Shah, K., Gupta, K., Sengupta, B., 2018. Reclamation of copper from spent ammoniacal Printed Circuit Board (PCB) etch solutions. J. Environ. Chem. Eng. $\quad$ 6, 2874-2880. Sharma, A.K., Singh, A., Mehta, R.K., Sharma, S., Bansal, S.P., Gupta, K.S., 2011. Kinetics of copper(II)-catalyzed oxidation of S(IV) by atmospheric oxygen in ammonia buffered solutions. Int. J. Chem. Kinet. $\quad$ 43, 379-392.

Smith, G.W., 1939. The Adsorption of Complex Ammonia Ions on Silica Gel. The Journal of Physical Chemistry 43, 637-646.

Smith, G.W., Jacobson, H.W., 1956. Characteristics of Adsorption of Complex MetalAmmines and other Complex Ions of Zinc, Copper, Cobalt, Nickel and Silver on Silica Gel. J. Phys. Chem. 60, 1008-1012.

Taha-Tijerina, J., Venkataramani, D., Aichele, C.P., Tiwary, C.S., Smay, J.E., Mathkar, A., Chang, P., Ajayan, P.M., 2015. Quantification of the Particle Size and Stability of Graphene Oxide in a Variety of Solvents. Part Part Syst Char 32, 334-339. 
Tominaga, H., Ono, Y., Keii, T., 1975. Spectroscopic study of $\mathrm{Cu}(\mathrm{II})$ ions supported on silica gel by cation exchange method. J. Catal. 40, 197-202.

van Loon, W.M.G.M., Boon, J.J., de Groot, B., 1993. Quantitative analysis of sulfonic acid groups in macromolecular lignosulfonic acids and aquatic humic substances by temperatureresolved pyrolysis-mass spectrometry. Environ. Sci. Technol. 27, 2387-2396.

Vijayaraghavan, K., Palanivelu, K., Velan, M., 2006. Biosorption of copper(II) and cobalt(II) from aqueous solutions by crab shell particles. Bioresour. Technol. 97, 1411-1419.

Villalobos, M., Trotz, M., Leckie, J., 2001. Surface Complexation Modeling of Carbonate Effects on the Adsorption of $\mathrm{Cr}(\mathrm{VI}), \mathrm{Pb}(\mathrm{II})$, and U(VI) on Goethite. Environ. Sci. Technol. 35, 3849-3856.

Weng, C.-H., Lin, Y.-T., Hong, D.-Y., Sharma, Y.C., Chen, S.-C., Tripathi, K., 2014. Effective removal of copper ions from aqueous solution using base treated black tea waste. Ecol. Eng. 67, 127-133.

Wijnja, H., Schulthess, C., 2002. Effect of Carbonate on the Adsorption of Selenate and Sulfate on Goethite. Soil Sci. Soc. Am. J. 66, 1190-1197.

Williamson, A.J., Verbruggen, F., Rico, V.S.C., Bergmans, J., Spooren, J., Yurramendi, L., Laing, G.D., Boon, N., Hennebel, T., 2020. Selective leaching of copper and zinc from primary ores and secondary mineral residues using biogenic ammonia. J. Hazard. Mater. 403, 123842.

Xiao, Y., Yang, Y., van den Berg, J., Sietsma, J., Agterhuis, H., Visser, G., Bol, D., 2013. Hydrometallurgical recovery of copper from complex mixtures of end-of-life shredded ICT products. Hydrometallurgy 140, 128-134. 


\section{Appendix A. Supplementary Data}

\section{Text A.1}

\section{Data analysis}

The $\mathrm{Cu}(\mathrm{II})$ removal efficiency (Eq. A.1) and adsorption capacity (Eq. A.2) of the biosorbents were calculated as follows:

$$
\begin{aligned}
& R=\frac{C_{0}-C_{e}}{C_{0}} \times 100 \\
& q=\frac{\left(C_{0}-C_{e}\right) \times V}{m}
\end{aligned}
$$

Where $R$ is the $\mathrm{Cu}(\mathrm{II})$ removal efficiency (\%), $q$ is the amount of $\mathrm{Cu}(\mathrm{II})$ adsorbed per unit mass of the biosorbent ( $\left.\mathrm{mmol} \mathrm{g}^{-1}\right), C_{0}$ and $C_{e}$ are the initial and equilibrium concentrations of $\mathrm{Cu}(\mathrm{II})$ $(\mathrm{mM})$ respectively, $V$ is the volume of the $\mathrm{Cu}-\mathrm{NH}_{3}$ solution (L), and $m$ is the mass of the biosorbent $(\mathrm{g})$.

Langmuir (Eq. A.3) and Freundlich (A.4) isotherm models were used to fit the experimental data of the biosorbents at different initial $\mathrm{Cu}(\mathrm{II})$ concentrations.

$$
\begin{aligned}
& q_{e}=\frac{q_{\max } b C_{e}}{1+b C_{e}} \\
& q_{e}=K_{f} C_{e}^{1 / n}
\end{aligned}
$$

Where $q_{\mathrm{e}}$ is the amount of $\mathrm{Cu}(\mathrm{II})$ adsorbed per unit mass of the biosorbent at equilibrium (mmol $\left.\mathrm{g}^{-1}\right), q_{\max }$ is the maximum adsorption capacity $\left(\mathrm{mmol} \mathrm{g}^{-1}\right), b$ is the Langmuir adsorption equilibrium constant $\left(\mathrm{L} \mathrm{mmol}{ }^{-1}\right), C_{\mathrm{e}}$ is the equilibrium $\mathrm{Cu}(\mathrm{II})$ concentration $(\mathrm{mM}), K_{\mathrm{f}}$ is the Freundlich constant $\left(\mathrm{mmol} \mathrm{g}^{-1}\right)\left(\mathrm{L} \mathrm{mmol}^{-1}\right)^{1 / \mathrm{n}}$, and $1 / \mathrm{n}$ is a dimensionless parameter that varies between 0 and 1.

The selectivity quotients (Eq. A.5) of the biosorbents were calculated as follows:

$$
K_{C u / Z n}=\frac{K_{d}^{C u}}{K_{d}^{Z n}}
$$

Where $K_{d}{ }^{C u}$ and $K_{d}{ }^{Z n}$ are the distribution coefficients for $\mathrm{Cu}$ and $\mathrm{Zn}$ calculated using Eq. A.6. 
$K_{d}=\frac{100-X}{X} \cdot \frac{V}{m}$

Where $X$ is the equilibrium concentration of either $\mathrm{Cu}$ (II) or $\mathrm{Zn}(\mathrm{II})$ in solution expressed as a percentage of the initial concentration, $V$ is the volume of the solution $(\mathrm{mL})$, and $m$ is the mass of the biosorbent ( $\mathrm{g}$ ). 


\section{Text A.2}

\section{Biosorbent characterizations}

\section{Fourier transform infrared spectroscopy}

Fourier transform infrared spectroscopy (FTIR) measurements were performed using a Thermo Scientific Nicolet 6700 FT-IR Spectrometer. Approximately $15 \mathrm{mg}$ of dried and ground biosorbent was placed on top of a potassium bromide $(\mathrm{KBr})$ disc for the analysis. FTIR spectra were recorded within the wavenumber range of 400 to $4000 \mathrm{~cm}^{-1}$ with spectral resolution of 4 $\mathrm{cm}^{-1}$ and 256 scans. The background obtained from the scan of pure $\mathrm{KBr}$ was automatically subtracted from each sample spectrum.

\section{Pore structure characterization}

The pore structure of each biosorbent was characterized by nitrogen adsorption-desorption measurements carried out at $77 \mathrm{~K}$ using a Micromeritics Tristar II 3020 apparatus. The samples were degassed at $60{ }^{\circ} \mathrm{C}$ under vacuum for at least $30 \mathrm{~h}$ prior to measurement. The BET specific surface area $\left(S_{B E T}\right)$ and the total pore volume $\left(V_{T}\right)$ of the biosorbents were determined using the BET method.

\section{Point of zero charge $\left(\mathrm{pH}_{P Z C}\right)$ determination}

The $\mathrm{pH}_{\mathrm{PZC}}$ of the biosorbents were determined using a batch equilibrium method described by Faria et al. (2004). Aliquots of $40 \mathrm{~mL}$ of $0.01 \mathrm{M} \mathrm{NaCl}$ were transferred to a series of $50-\mathrm{mL}$ polypropylene tubes. The initial $\mathrm{pH}$ of each solution was adjusted to a value from 3 to 11 with one $\mathrm{pH}$ unit increment. Then, $0.12 \mathrm{~g}$ of the biosorbent was added to each tube. The suspensions were shaken at $115 \mathrm{rpm}$ for $48 \mathrm{~h}$ in an orbital shaker to allow equilibrium. Afterwards, the final $\mathrm{pH}$ of the solutions was measured. For each biosorbent, the initial $\mathrm{pH}$ value $\left(\mathrm{pH}_{0}\right)$ was plotted versus the difference between the initial and final $\mathrm{pH}$ values $\left(\mathrm{pH}_{0}-\mathrm{pH}_{\mathrm{f}}\right)$ and the $\mathrm{pH}_{\mathrm{PZC}}$ was calculated as the point where the curve intersects the $\mathrm{x}$-axis (i.e., $\mathrm{pH}_{0}=\mathrm{pH}_{\mathrm{f}}$ ). 


\section{Acidic and basic surface properties}

The surface groups of the biosorbents giving the acidic and basic surface properties were estimated using Boehm titration (Boehm, 2002). Each biosorbent $(0.4 \mathrm{~g})$ was mixed with 40 $\mathrm{mL}$ of the following solutions separately: $0.1 \mathrm{M} \mathrm{NaHCO}_{3}, 0.05 \mathrm{M} \mathrm{Na}_{2} \mathrm{CO}_{3}, 0.1 \mathrm{M} \mathrm{NaOH}$, and 0.1 M HCl. The suspensions were shaken in an orbital shaker at $115 \mathrm{rpm}$ for $48 \mathrm{~h}$. Subsequently, $10 \mathrm{~mL}$ of each suspension was titrated with either $0.05 \mathrm{M} \mathrm{HCl}$ or $\mathrm{NaOH}$ depending on the starting solution. To calculate the concentrations of the surface oxygen groups, it was assumed that (1) $\mathrm{NaHCO}_{3}$ reacts with carboxylic groups only, (2) $\mathrm{Na}_{2} \mathrm{CO}_{3}$ reacts with both carboxylic and lactonic groups, and (3) $\mathrm{NaOH}$ reacts with carboxylic, lactonic, and phenolic groups. The quantification of basic sites was also calculated from the amount of $\mathrm{HCl}$ that reacted with the biosorbents.

$X$-ray photoelectron spectroscopy (XPS)

XPS analyses of raw and Cu-adsorbed PC were performed on S-Probe Monochromatized XPS spectrometer (Surface Science Instruments, VG) with monochromatic AlK $\alpha$ X-ray (1486.6 $\mathrm{eV}, 200 \mathrm{~W}$ ) source. The low-resolution spectra were collected with a pass energy $\mathrm{E}_{\mathrm{p}}=140.9$ $\mathrm{eV}$ and energy steps $E_{\mathrm{s}}=0.24 \mathrm{eV}$, while the high-resolution spectra with $\mathrm{E}_{\mathrm{p}}=140.9 \mathrm{eV}$ and $\mathrm{E}_{\mathrm{s}}$ $=0.15 \mathrm{eV}$. The XPS spectra were analyzed using CasaXPS Software. 


\section{Text A.3}

\section{Chemical speciation modeling}

The speciation of $\mathrm{Cu}(\mathrm{II})$ and $\mathrm{Zn}(\mathrm{II})$ in the presence of $\mathrm{NH}_{3}$ and $\mathrm{CO}_{3}{ }^{2-}$ in aqueous solutions was determined using the Hydra-Medusa software. Hydra contains a database with the logarithm of equilibrium constants $(\log \mathrm{K})$ at $25{ }^{\circ} \mathrm{C}$, while Medusa creates the different equilibrium diagrams (e.g., species fraction, logarithmic, and predominance area diagrams) (Puigdomenech, 2013). The initial concentration of each component in the defined system was used as the input to plot the fraction of the predominant metal species as a function of the solution $\mathrm{pH}$. 
Table A.1. Main properties of the biosorbents pinecone (PC), Fucus spiralis (FS), chitosan (CT), sewage sludge biochar (SSBC500), and lignin-rich digested stillage (LRD).

\begin{tabular}{lccccc}
\hline & PC & FS & CT & SSBC500 & LRD \\
\hline $\mathrm{pH}$ PZC & 5.06 & 5.97 & $6.60^{\dagger}$ & 7.49 & 6.34 \\
$\mathrm{~S}_{\text {BET }}\left(\mathrm{m}^{2} \mathrm{~g}^{-1}\right)$ & 0.6 & $\sim 0$ & 0.8 & 3.2 & 3.8 \\
$\mathrm{~V}_{\mathrm{T}}\left(\mathrm{cm}^{3} \mathrm{~g}^{-1}\right)$ & 0.001 & $<0.001$ & 0.002 & 0.007 & 0.014 \\
\hline
\end{tabular}

\section{Surface sites}

\begin{tabular}{|c|c|c|c|c|c|}
\hline Carboxylic & 0.38 & 0.12 & N.D. & 0.11 & 0.96 \\
\hline Lactonic & 0.23 & 0.39 & N.D. & 0.03 & 0.15 \\
\hline Phenolic & 0.67 & 0.36 & N.D. & 0.79 & 0.01 \\
\hline Basic sites & 0.16 & 1.38 & N.D. & 0.48 & 1.27 \\
\hline
\end{tabular}


Table A.2. Analysis of the FTIR spectra peaks of the raw biosorbents.

\begin{tabular}{ll}
\hline Pinecone (PC) & \\
\hline Peak position $\left(\mathbf{c m}^{-1}\right)$ & Assignment \\
\hline 3450 & unbounded -OH group \\
2933 & aliphatic C-H group stretching \\
1722 & C=O stretch (non-cyclic esters - lactones) \\
1612 & C=C (aromatic skeletal mode of lignin) and C=O (carboxylic acids) \\
1510 & aromatic ring vibrations likely from the lignin fraction of the plant \\
1440 & material \\
1272 & - COO- (carboxylate salts) \\
1109 & C-N stretching with amine \\
\hline
\end{tabular}

Fucus spiralis (FS)

\begin{tabular}{ll}
\hline Peak position $\left(\mathbf{c m}^{-1}\right)$ & Assignment \\
\hline 3332 & stretching vibration of $\mathrm{O}-\mathrm{H}$ group \\
2924 & asymmetric stretch of aliphatic chains $(-\mathrm{CH})$ \\
1741 & $\mathrm{C}=\mathrm{O}$ stretch of $\mathrm{COOH}$ \\
1664 & asymmetric $\mathrm{C}=\mathrm{O}$ \\
1531 & asymmetric stretching vibrations of $\mathrm{COO}^{-}$group \\
1444 & symmetric stretching vibrations of $\mathrm{COO}^{-}$group \\
1261 & stretching vibration of the bond $\mathrm{C}^{-} \mathrm{S}$ which is characteristic of \\
& sulfonic acid \\
& $\mathrm{C}-\mathrm{O}$ (ether) \\
820 & $\mathrm{~S}=\mathrm{O}$ stretch \\
\hline
\end{tabular}

Chitosan (CT)

\begin{tabular}{ll}
\hline Peak position $\left(\mathbf{c m}^{-1}\right)$ & Assignment \\
\hline 3433 & $\mathrm{~N}-\mathrm{H}$ and $\mathrm{O}-\mathrm{H}$ stretching \\
2918,2864 & $\mathrm{C}-\mathrm{H}$ symmetric stretching \\
1662 & $\mathrm{C}=\mathrm{O}$ stretching of amide I (presence of residual $\mathrm{N}$-acetyl groups) \\
1554 & $\mathrm{~N}-\mathrm{H}$ bending of amide II \\
1385 & $\mathrm{CH}_{3}$ symmetrical deformations \\
1144 & asymmetric stretching of the $\mathrm{C}-\mathrm{O}-\mathrm{C}$ bridge
\end{tabular}


1070, 1043

C-O stretching

Sewage sludge biochar (SSBC500)

\begin{tabular}{|c|c|}
\hline Peak position $\left(\mathrm{cm}^{-1}\right)$ & Assignment \\
\hline 3352 & $\begin{array}{l}\text { generally attributed to } \mathrm{O}-\mathrm{H} \text { and secondarily to } \mathrm{N}-\mathrm{H} \text { stretching of } \\
\text { various functional groups in } \mathrm{H} \text { bonding }\end{array}$ \\
\hline 3049 & aliphatic $\mathrm{C}-\mathrm{H}$ stretching \\
\hline 1581 & $\begin{array}{l}\text { aromatic } \mathrm{C}=\mathrm{O} \text { stretching vibration and the } \mathrm{C}=\mathrm{C} \text { stretching vibration } \\
\text { of carboxylic acids esters, ketones, and anhydrides }\end{array}$ \\
\hline 1150 & organic $\mathrm{C}-\mathrm{OH}$ stretching of carbohydrates \\
\hline 1047 & $\mathrm{C}-\mathrm{O}$ stretching vibration \\
\hline
\end{tabular}

Lignin-rich digested stillage (LRD)

\begin{tabular}{ll}
\hline Peak position $\left(\mathbf{c m}^{-\mathbf{1}}\right)$ & Assignment \\
\hline 3360 & aliphatic and phenolic OH-groups \\
2927 & alkane C-H stretching \\
$1666,1591,1506$, & $\mathrm{C}=\mathrm{C}$ stretching in the aromatic rings \\
1454,1423 & \\
1317 & $\mathrm{C}-\mathrm{O}-\mathrm{C}$ symmetric stretching \\
1263,1228 & $\mathrm{C}=\mathrm{O}$ stretching \\
1115,1063 & $\mathrm{C}-\mathrm{O}-\mathrm{C}$ symmetric stretching
\end{tabular}




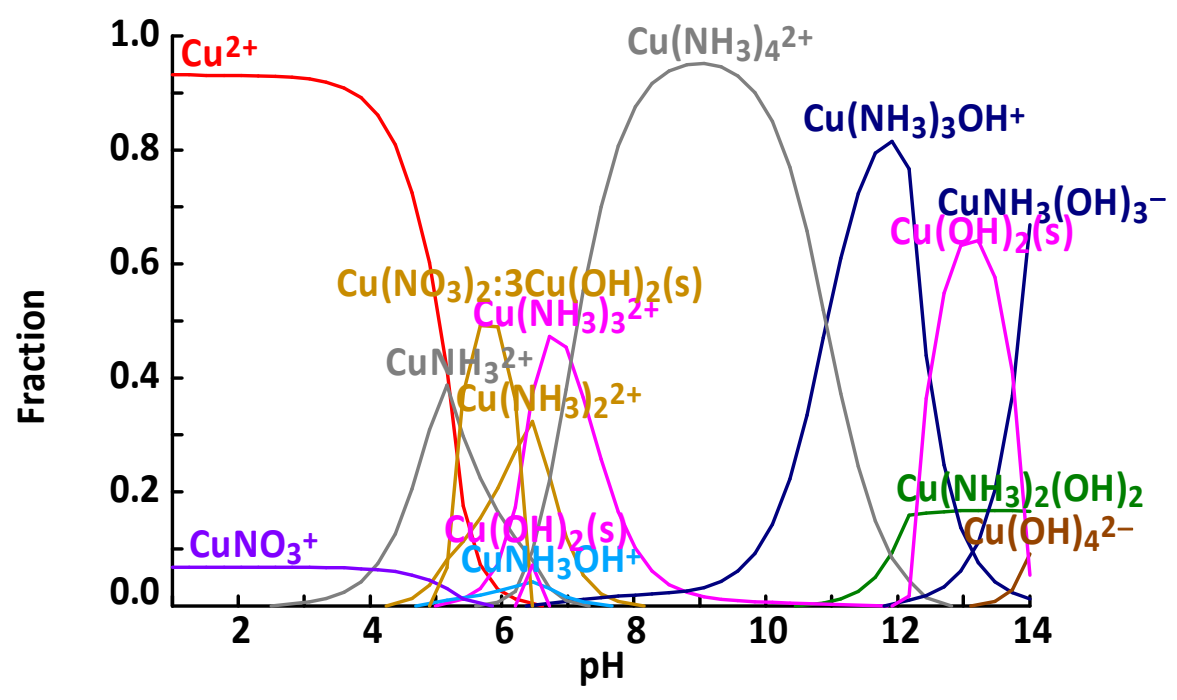

Fig. A.1. Chemical speciation of $12 \mathrm{mM} \mathrm{Cu}$ (II) in the presence of $1 \mathrm{M} \mathrm{NH}_{3}$ estimated using the Hydra-Medusa software. 

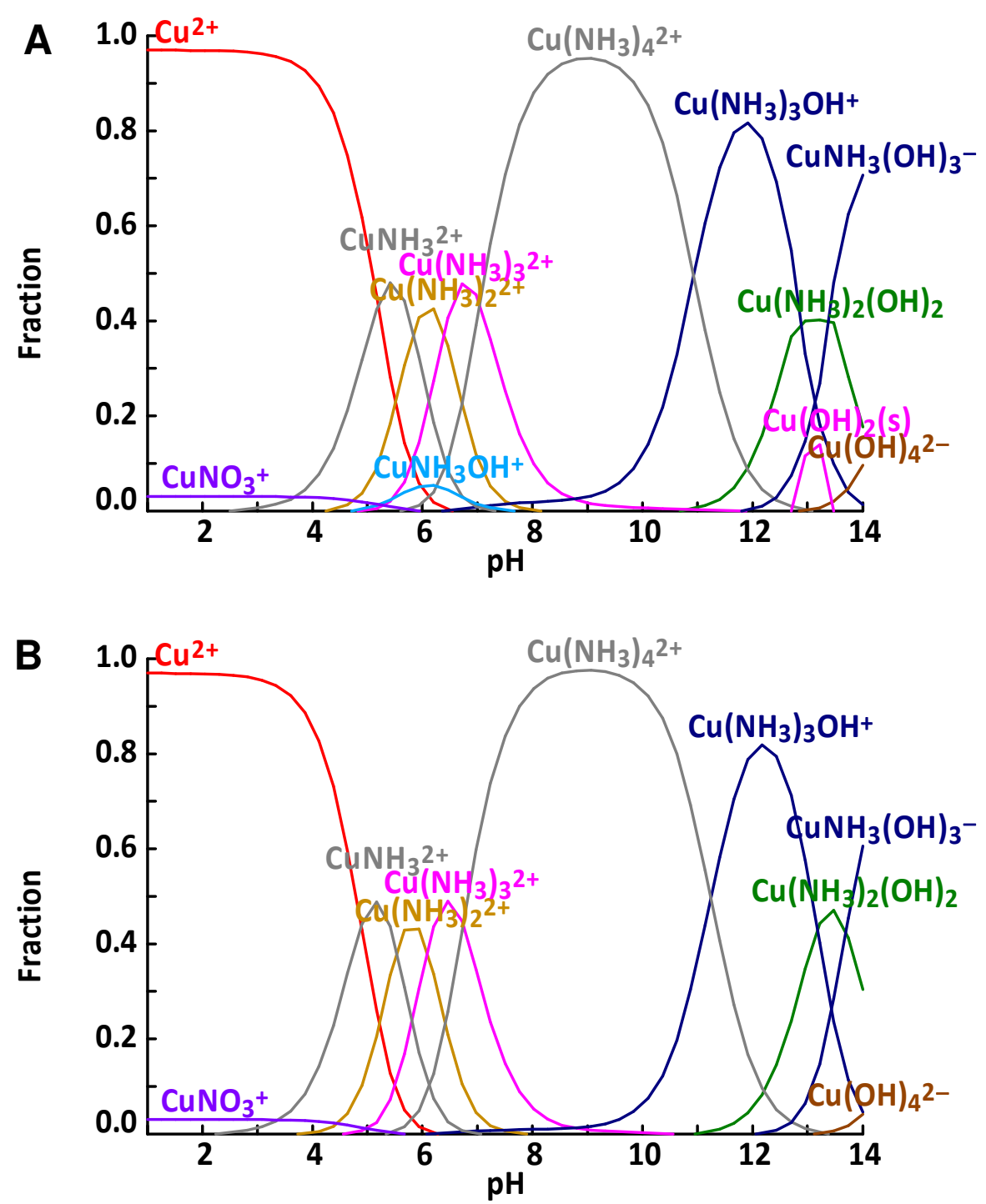

Fig. A.2. Chemical speciation of $5 \mathrm{mM} \mathrm{Cu}$ (II) in aqueous solution in the presence of (A) $1 \mathrm{M}$ or (B) $2 \mathrm{M} \mathrm{NH}_{3}$ estimated using the Hydra-Medusa software. 


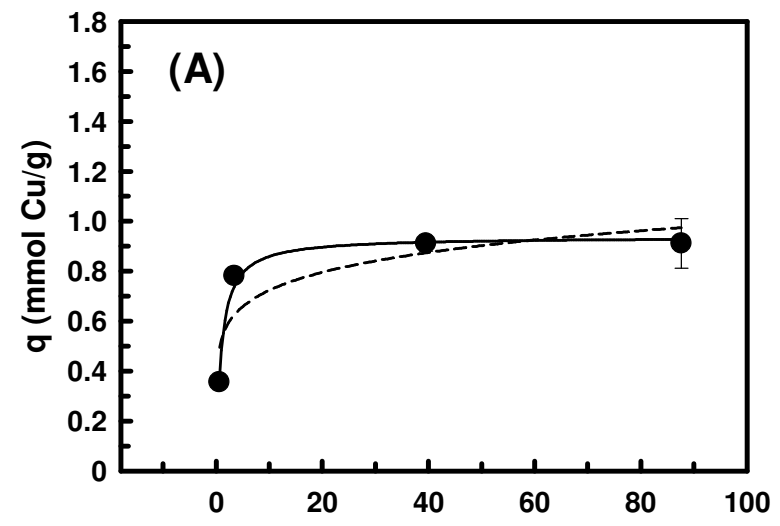

Equilibrium concentration, $\mathrm{C}_{\mathrm{e}}(\mathrm{mmol} / \mathrm{L})$

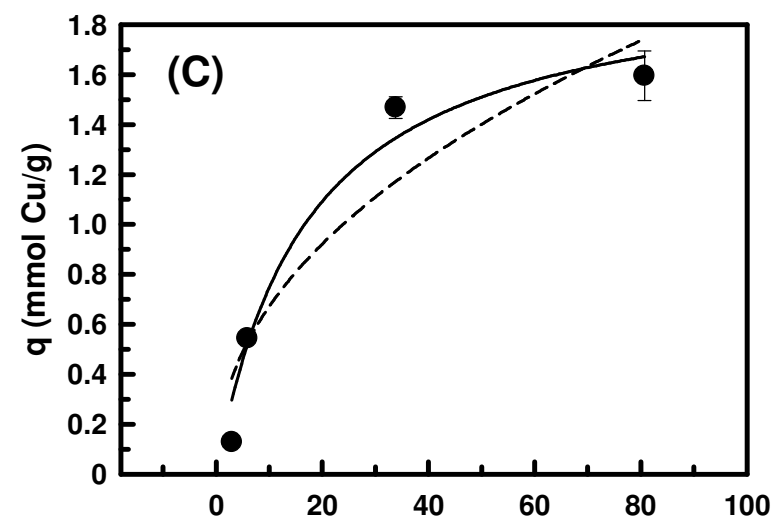

Equilibrium concentration, $\mathrm{C}_{\mathrm{e}}(\mathrm{mmol} / \mathrm{L})$
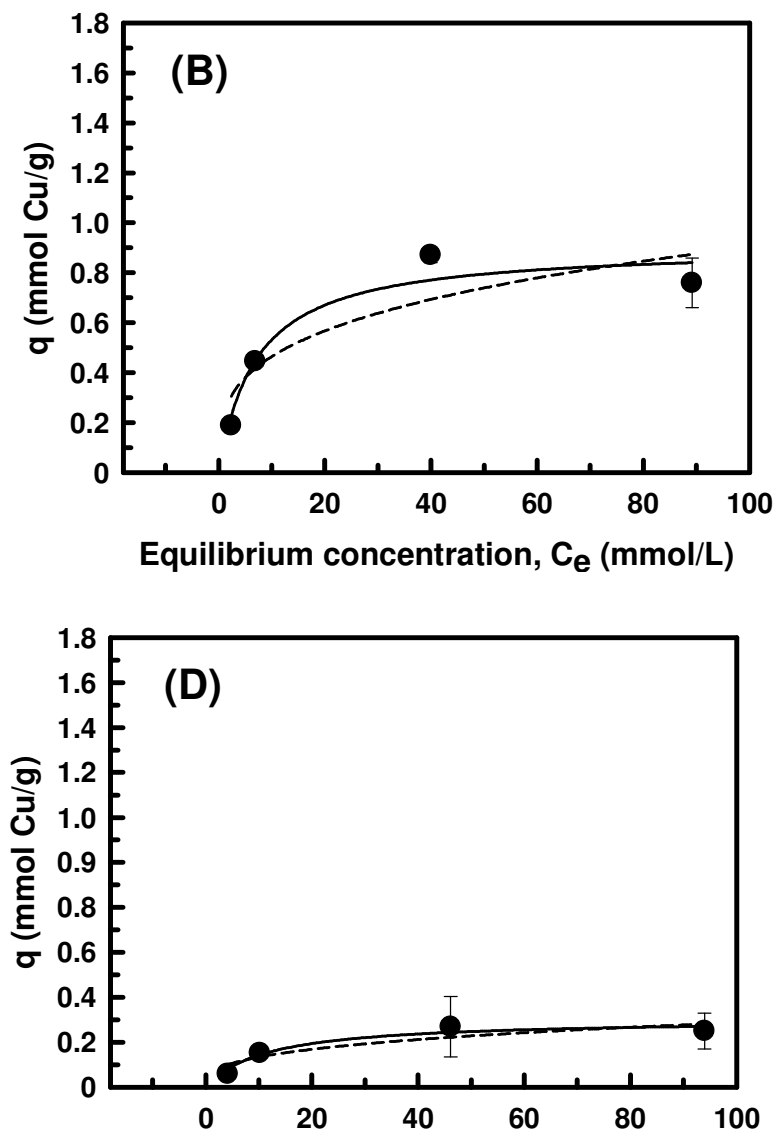

Equilibrium concentration, $\mathrm{C}_{\mathrm{e}}(\mathrm{mmol} / \mathrm{L})$

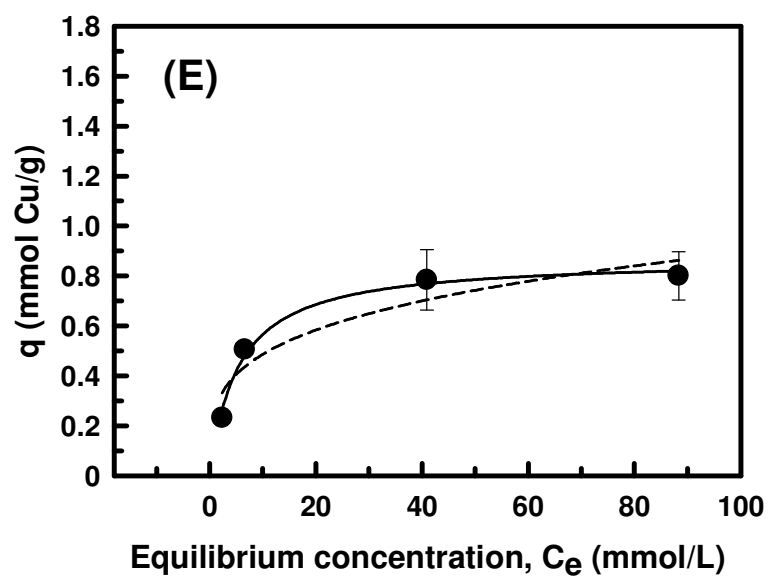

Fig. A.3. Langmuir (solid) and Freundlich (dashed) isotherm models of $\mathrm{Cu}(\mathrm{II})$ adsorption onto (A) PC, (B) FS, (C) CT, (D) SSBC500, and (E) LRD in the presence of $\mathrm{NH}_{3}$. Experimental conditions: $2 \mathrm{M} \mathrm{NH}_{3}, 100 \mathrm{~mL} \mathrm{~g}^{-1} \mathrm{~L} / \mathrm{S}$ ratio, $\mathrm{pH}$ 11, room temperature (RT), 24 h contact time. 

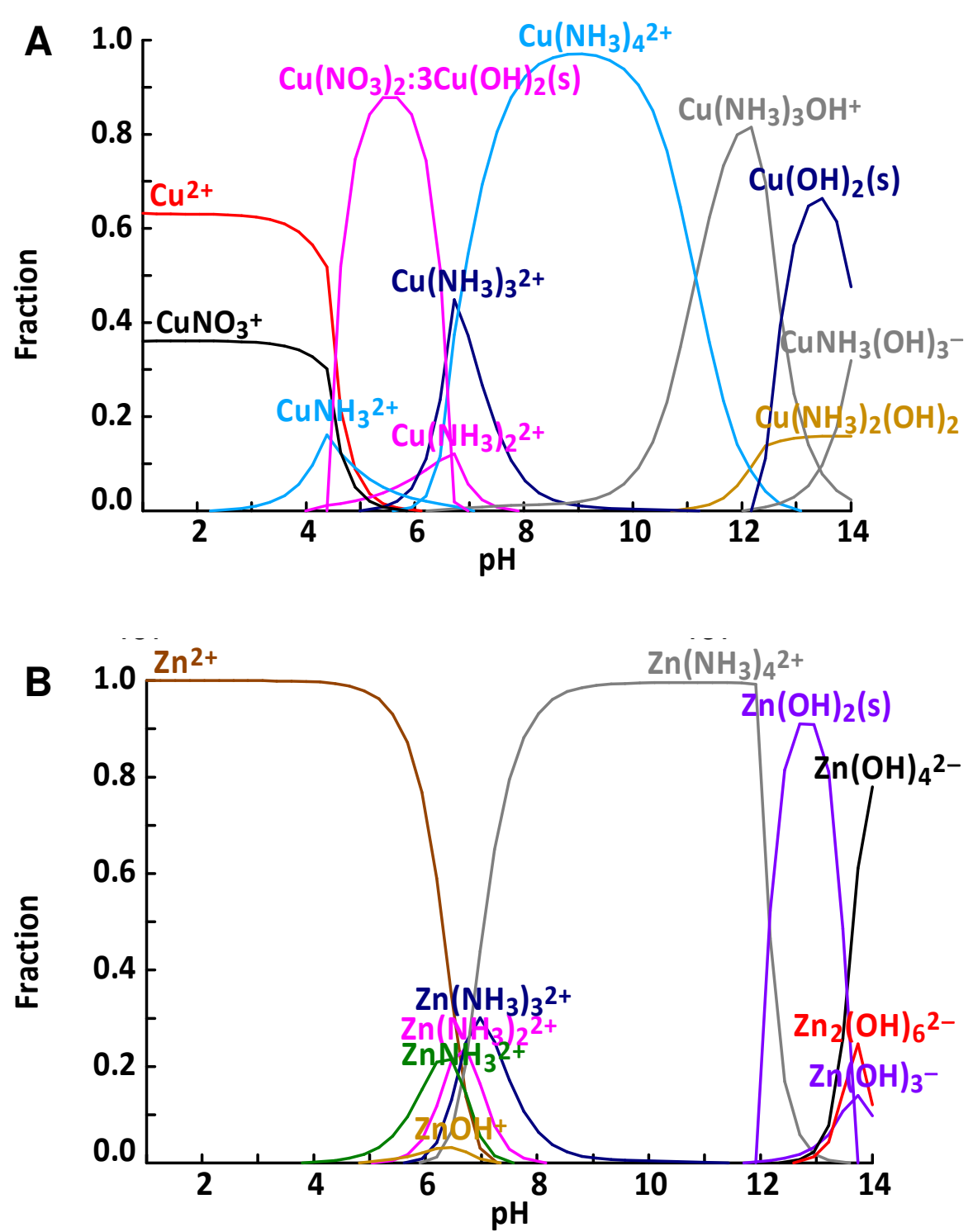

Fig. A.4. Chemical speciation of (A) $50 \mathrm{mM} \mathrm{Cu}$ (II) in the presence of $50 \mathrm{mM} \mathrm{Zn(II)}$ and $2 \mathrm{M}$ $\mathrm{NH}_{3}$ and (B) $50 \mathrm{mM} \mathrm{Zn}$ (II) in the presence of $50 \mathrm{mM} \mathrm{Cu}$ (II) and $2 \mathrm{M} \mathrm{NH}_{3}$ estimated using the Hydra-Medusa software. 


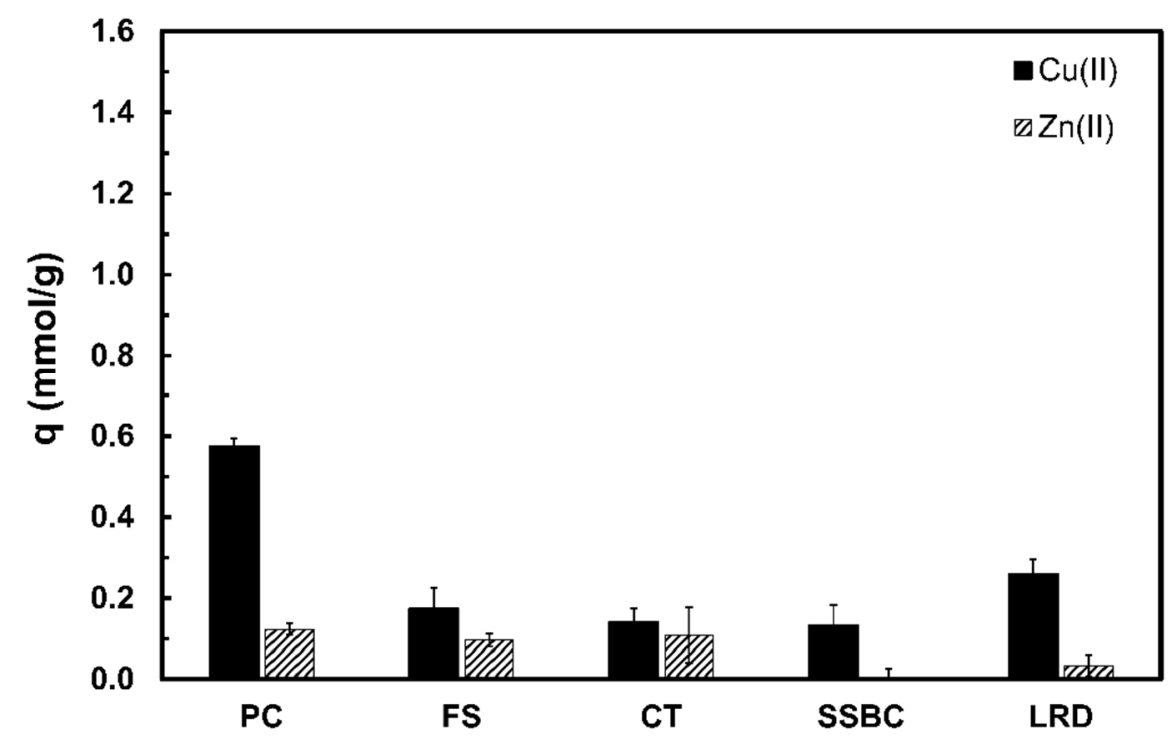

Fig. A.5. $\mathrm{Cu}(\mathrm{II})$ and $\mathrm{Zn}(\mathrm{II})$ adsorption capacities of PC, FS, CT, SSBC500, and LRD in binary metal solutions containing $\mathrm{NH}_{3}$. Experimental conditions: $50 \mathrm{mM} \mathrm{Cu}(\mathrm{II}), 50 \mathrm{mM} \mathrm{Zn}(\mathrm{II}), 2 \mathrm{M}$ $\mathrm{NH}_{3}, 100 \mathrm{~mL} \mathrm{~g}^{-1} \mathrm{~L} / \mathrm{S}$ ratio, $\mathrm{pH}$ 9, $\mathrm{RT}, 24$ h contact time. 

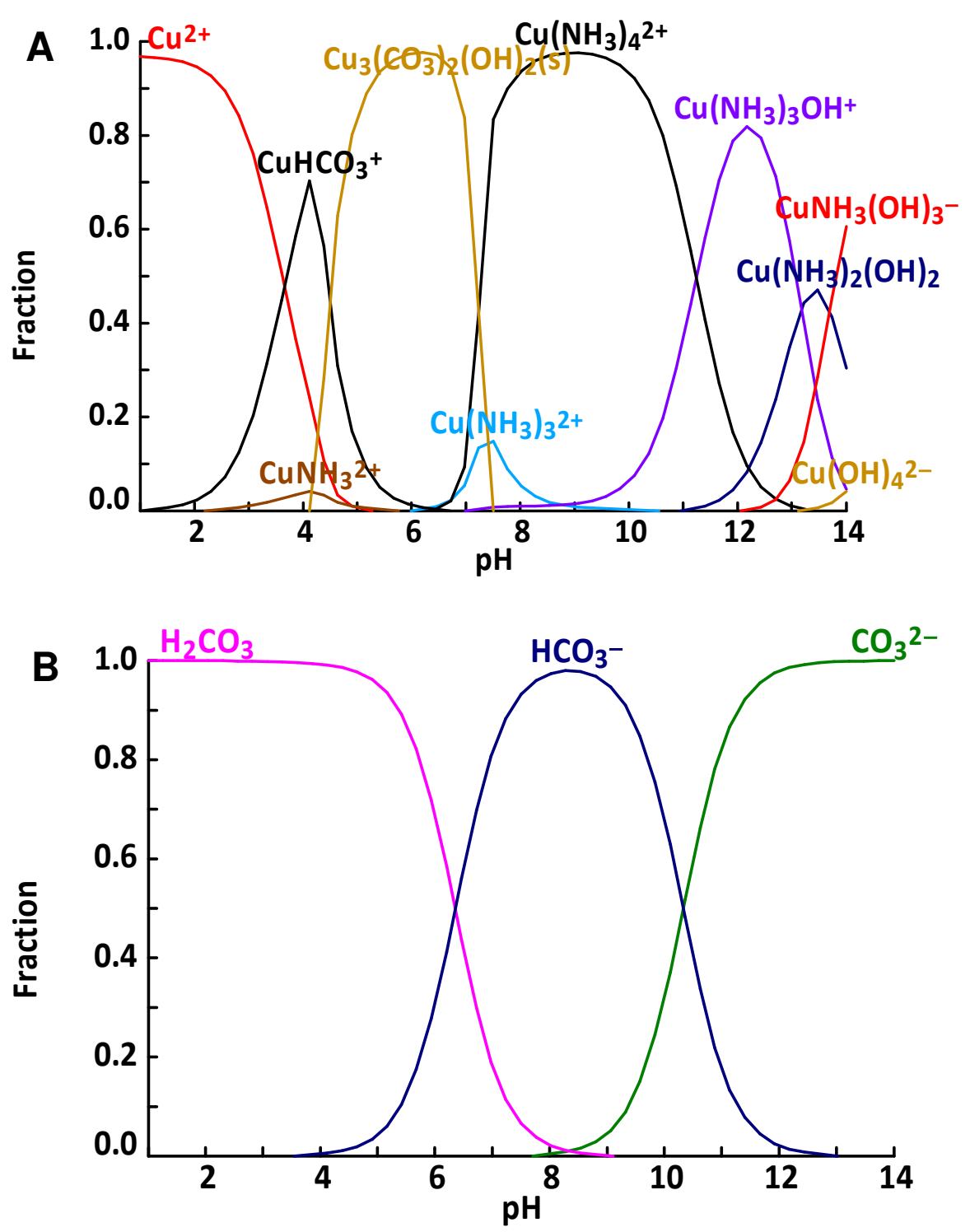

Fig. A.6. Chemical speciation of (A) $5 \mathrm{mM} \mathrm{Cu}$ (II) in the presence of $2 \mathrm{M} \mathrm{NH}_{3}$ and $1 \mathrm{M} \mathrm{CO}_{3}{ }^{2-}$ and (B) $1 \mathrm{M} \mathrm{CO}_{3}{ }^{2-}$ in the presence of $5 \mathrm{mM} \mathrm{Cu}$ (II) and $2 \mathrm{M} \mathrm{NH}_{3}$ estimated using the HydraMedusa software. 


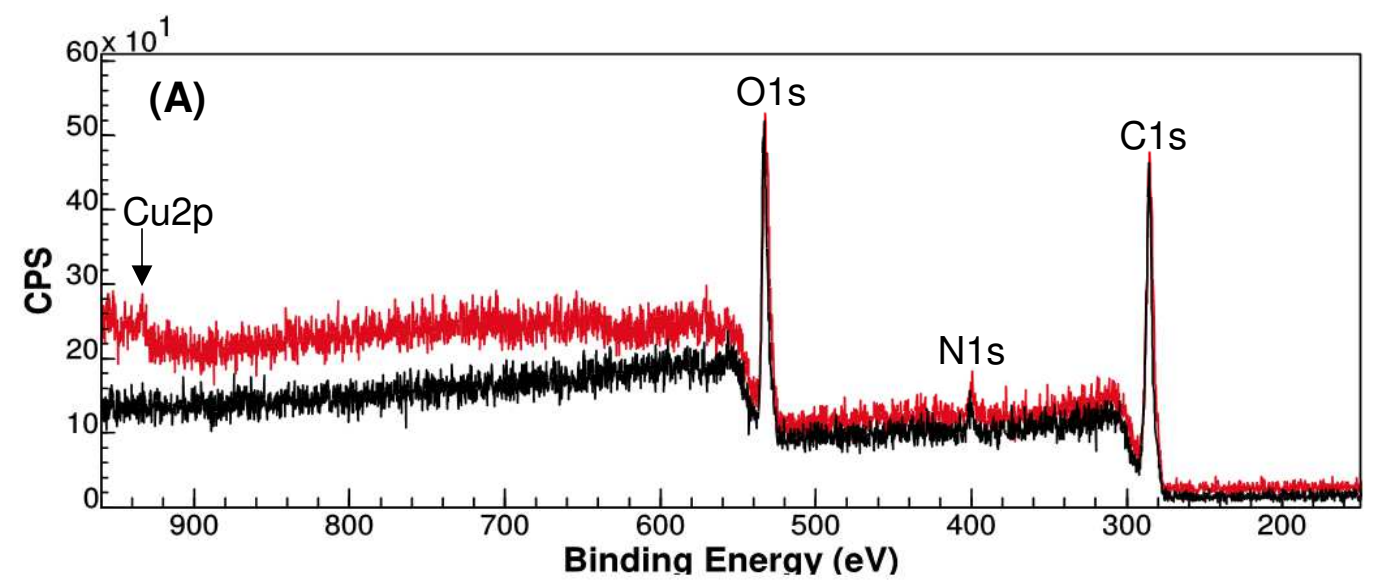

C1s
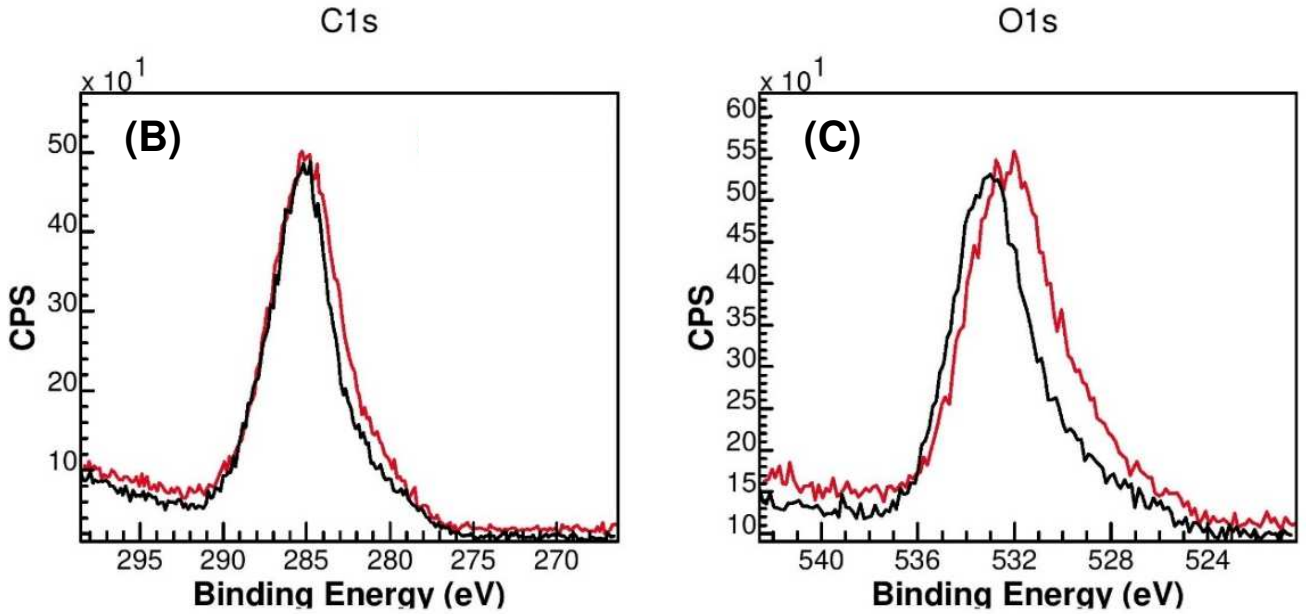

N1s
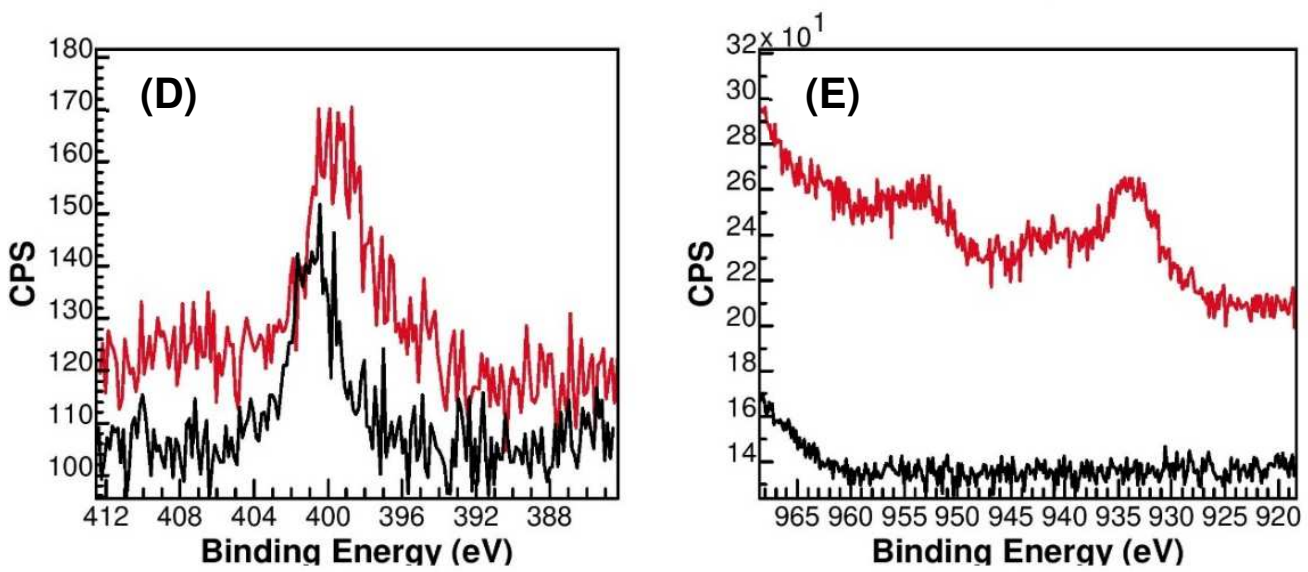

Fig. A.7. (A) XPS survey spectra of raw PC (black) and Cu-loaded PC (red) and high-resolution XPS scan spectra over (B) C 1s; (C) O 1s; (D) N 1s; and (E) Cu 2p of raw PC (black) and Culoaded PC (red). The spectra are plotted as counts per second (CPS) versus the binding energy. Note: The spectra noise is due to the short acquisition time that had to be used to avoid the Xray photoreduction of $\mathrm{Cu}(\mathrm{II})$ ions. 


\section{References}

Boehm, H.P., 2002. Surface oxides on carbon and their analysis: a critical assessment. Carbon 40, 145-149.

Caje, J., de Oliveira, P., Semaan, F., Cruz, R., Cassella, R., Pacheco, W., 2017. Sorption Properties of Methyl Orange onto Chemically Modified Chitosan: Thermodynamics and Kinetics Studies. SM Anal Bioanal Technique 2, 1006-1014.

Faria, P.C.C., Órfão, J.J.M., Pereira, M.F.R., 2004. Adsorption of anionic and cationic dyes on activated carbons with different surface chemistries. Water Res. 38, 2043-2052.

Fras, L., Ristić, T., Tkavc, T., 2012. Adsorption and Antibacterial Activity of Soluble and Precipitated Chitosan on Cellulose Viscose Fibers. J. Eng. Fibers Fabr. 7, 50-57.

Gür, E., Altinisik, A., Yurdakoc, K., 2017. Preparation and characterization of chitosan/sepiolite bionanocomposites for tetracycline release. Polym. Compos. 38, 1810-1818. Marques Neto, J.d.O., Bellato, C.R., Milagres, J.L., Pessoa, K.D., Alvarenga, E.S.d., 2013. Preparation and evaluation of chitosan beads immobilized with Iron(III) for the removal of As(III) and As(V) from water. J. Braz. Chem. Soc. 24, 121-132.

Puigdomenech, I., 2013. Chemical Equilibrium Diagrams. . 